\title{
Penyajian Laporan Keuangan Berdasarkan Standar Akuntansi Pemerintahan Nomor 71 Tahun 2010 Pada Inspektorat Kabupaten Enrekang
}

\author{
Andry Kusuma ${ }^{*}$, Abdul Rahman Mus², Darwis Lannai ${ }^{3}$ \\ ${ }^{1}$ Mahasiswa Magister Ilmu Manajemen, Program Pascasarjana Universitas Muslim Indonesia, Makassar. \\ ${ }^{2}$ Fakultas Ekonomi dan Bisnis, Jurusan Manajemen, Universitas Muslim Indonesia, Makassar. \\ ${ }^{3}$ Fakultas Ekonomi dan Bisnis, Jurusan Akuntansi, Universitas Muslim Indonesia, Makassar. \\ Email Korespondensi:
}

\begin{abstract}
Abstrak
Penyajian Laporan Keuangan berdasarkan Standar Akuntansi Pemerintahan Nomor 71 Tahun 2010 Pada Inspektorat Kabupaten Enrekang. (dibimbing oleh dan Abdul Rahman Mus dan Darwis Lannai). Penelitian ini bertujuan untuk mengetahui dan menganalisis penyajian laporan keuangan Inspektorat Kab. Enrekang telah sesuai dengan SAP. Data yang digunakan adalah data sekunder yaitu laporan keuangan Inspektorat Kabupaten Enrekang tahun 2019. Data diperoleh dengan melakukan dokumentansi dan wawancara. Metode analisis yang digunakan adalah metode analisis deskriptif. Hasil dari penelitian ini menunjukkan bahwa laporan keuangan Inspektorat Kabupaten Enrekang telah menerapkan PP nomor 71 tahun 2010 tentang Standar Akuntansi Pemerintahan
\end{abstract}

Kata Kunci: Laporan Keuangan, Standar Akuntansi Pemerintahan, Peraturan Pemerintah Nomor 71 Tahun 2010

\section{Pendahuluan}

Salah satu bentuk kongkrit untuk meningkatkan transparansi dan akuntabilitas dalam pengelolaan keuangan negara adalah dengan melakukan pengembangan kebijakan akuntansi pemerintah berupa Standar Akuntansi Pemerintahan (SAP) yang bertujuan untuk memberikan pedoman pokok dalam penyusunan dan penyajian laporan keuangan pemerintah baik pemerintah pusat maupun pemerintah daerah (Indonesia, 2010). Tahun 2010 terbit Peraturan Pemerintah (PP) Nomor 71 tahun 2010 tentang Standar Akuntansi Pemerintahan sebagai pengganti PP Nomor 24 tahun 2005 terdiri dari tiga lampiran utama yaitu : Lampiran I standar akuntansi pemerintah berbasis akrual, Lampiran II standar akuntansi berbasis kas menuju akrual, Lampiran III proses penyusunan standar akuntansi pemerintah berbasis akrual. Berlakunya PP Nomor 71 tahun 2010 tentang Standar Akuntansi Pemerintah berbasis akrual membawa perubahan besar dalam sistem pelaporan keuangan di Indonesia, yaitu perubahan dari basis kas menuju akrual menjadi basis akrual penuh dalam pengakuan transaksi keuangan pemerintah. Diharapkan dengan adanya perubahan basis tersebut mampu memberikan gambaran yang lengkap atas posisi keuangan pemerintah dan menyajikan informasi yang sebenarnya mengenai hak dan kewajiban pemerintah (Duwi, 2016; Mentu \& Sondakh, 2016; Sampel et al., 2015).

Menanggapi dikeluarkannya PP 71 Tahun 2020, Pemerintah Kabupaten Enrekang mengeluarkan Peraturan Bupati Enrekang Nomor 40 Tahun 2015 tentang Kebijakan Akuntansi Pemerintah Kab. Enrekang sebagai dasar aturan bagi pihak Organisasi Perangkat Daerah (OPD) dalam membuat laporan keuangan berbasis akrual . Aturan-aturan tersebut menjadi pedoman bagi para pengelola keuangan yang ada di setiap OPD lingkup Kabupaten Enrekang dalam menyusun laporan berbasis akrual. Inspektorat Kabupaten Enrekang sebagai salah satu OPD yang ada di wilayah Pemerintah Kab. Enrekang sekaligus sebagai pengguna anggaran juga harus membuat pertanggungjawaban atas kewenangan yang dilaksanakannya berupa laporan keuangan yang disajikan sesuai PP Nomor 71 Tahun 2010 tentang Standar Akuntansi Pemerintahan. Namun, dalam mendukung penyajian laporan keuangan sesuai dengan SAP berbasis akrual, diperlukan faktor pendukung berupa SDM yang 
mempunyai latar belakang pendidikan akuntansi dan harus didukung dengan perangkat pendukung teknis. Fenomena yang terjadi pada Inspektorat Kab. Enrekang adalah masih terdapat fakta terjadi keterlambatan penyampaian laporan keuangan pada saat review yang dilakukan oleh tim reviu inspektorat Kab. Enrekang. Keterlambatan penyampaian laporan keuangan ini dikarenakan keterlambatan penyampaian data-data keuangan seperti data beban dibayar di muka yaitu pembayaran surat tanda kendaraan bermotor dan data akumulasi penyusutan aset tetap milik Inspektorat Kab. Enrekang yang selama ini dihitung secara manual tanpa menggunakan aplikasi.

Penelitian terkait penyajian laporan keuangan sesuai PP Nomor 71 Tahun 2010 tentang Akuntansi Pemerintahan telah dilakukan oleh Mentu dan Sondakh (2016). Hasil penelitian Mentu dan Sondakh (2016) menunjukkan bahwa penyajian laporan keuangan pada Dinas Pendapatan Daerah dan Dinas sosial Provinsi Sulawesi Utara belum sesuai dengan PP No.71 tahun 2010. Hasil penelitian yang berbeda telah ditemukan oleh Purba (2017) menunjukkan bahwa Pemerintah kabupaten Deli Serdang telah menyajikan laporan keuangannya sesuai dengan Peraturan Pemerintah Nomor 71 tahun 2010 dan Peraturan Menteri Dalam Negeri Nomor 64 tahun 2013. Sarana pendukung berupa komputer sudah memadai dan aplikasi SIMDA sudah digunakan dalam penyajian laporan keuangan daerah. Pegawai yang berlatar belakang pendidikan akuntansi sudah memadai tetapi penempatan pegawai sebagai kepala sub bagian keuangan masih sangat kurang. Dengan adanya fenomena yang terjadi dan perbedaan hasil-hasil penelitian terdahulu sehingga menarik minat peneliti untuk melakukan penelitian lebih lanjut dengan judul "Penyajian Laporan Keuangan Berdasarkan Standar Akuntansi Pemerintahan Nomor 71 Tahun 2010 Pada Inspektorat Kabupaten Enrekang. Oleh karenanya, studi ini mengalamatkan rumusan masalah dan tujuan penelitian yakni:

Tabel 1: Rumusan dan Tujuan Penelitian

\begin{tabular}{|l|l|}
\hline \multicolumn{1}{|c|}{ Rumusan Masalah } & \multicolumn{1}{|c|}{ Tujuan Penelitian } \\
\hline 1. Apakah penyajian laporan keuangan Inspektorat \\
$\begin{array}{l}\text { Kabupaten Enrekang tahun 2019 telah sesuai } \\
\text { dengan Standar Akuntansi Pemerintahan Nomor }\end{array}$ & $1 . \quad \begin{array}{l}\text { untuk mengetahui dan menganalisis penyajian } \\
\text { laporan keuangan Inspektorat Kabupaten } \\
\text { 71 Tahun 2010? }\end{array}$ \\
\hline
\end{tabular}

Adapun kegunaan yang dapat diperoleh dari penelitian ini, yakni sebagai berikut: (1) Bagi peneliti diharapkan dapat menjadi tambahan ilmu pengetahuan dan wawasan dalam menerapkan teori dari hasil penelitian yang diperoleh pada tempat peneliti bekerja. (2) Bagi akademik penelitian ini diharapkan dapat menambah wawasan dan pengetahuan dalam ilmu Akuntansi Sektor Publik khususnya tentang Penyajian Laporan Keuangan Pemerintahan Berbasis Akrual dan diharapkan dapat menjadi bahan referensi untuk melakukan penelitian lanjutan mengenai Penyajian Laporan Keuangan pemerintahan berbasis akrual. (3) Bagi Pemerintah Kabupaten Enrekang diharapkan menjadi bahan masukan dalam penerapan SAP Berbasis Akrual.

\section{Tinjauan Pustaka}

\subsection{Teori Keagenan}

Teori keagenan (agency theory) awalnya dikemukakan oleh Berle dan Means pada tahun 1932 (Mizruchi, 2004) yang dikembangkan oleh Jensen \& Meckling (1976) yaitu menjelaskan bagaimana pihak yang terkait dalam suatu entitas yaitu pemerintah pusat, pemerintah daerah, DPRD dan masyarakat akan berperilaku, karena mereka pada dasarnya memiliki kepentingan yang berbeda. Mengacu pada teori keagenan (agency theory), dimaknai dengan adanya kewajiban pihak pemegang amanah (agent) untuk memberikan pertanggungjawaban, menyajikan, melaporkan dan mengungkapkan segala aktifitas dan kegiatan yang menjadi tanggungjawabnya kepada pihak pemberi amanah (principal) yang memiliki hak dan kewenangan untuk meminta pertanggungjawaban tersebut (Eisenhardt, 1989) . Berkaitan dengan masalah keagenan, praktek pelaporan keuangan dalam organisasi sektor publik merupakan suatu konsep yang didasari oleh teori keagenan. Dalam pelaporan keuangan yang berkualitas, pemerintah yang bertindak sebagai agen mempunyai kewajiban menyajikan informasi yang bermanfaat bagi para pengguna informasi keuangan pemerintah yang bertindak sebagai prinsipal dalam menilai akuntabilitas dan membuat keputusan baik keputusan ekonomi, sosial maupun politik. Dalam suatu pemerintahan demokrasi, hubungan antara pemerintah dan para pengguna informasi keuangan pemerintah dapat digambarkan sebagai suatu hubungan keagenan 
(agency relationship) (Mitnick, 2015). Kaitan teori keagenan dalam penelitian ini adalah menjelaskan tentang praktek pelaporan keuangan yang baik (berkualitas) di pemerintah daerah. Dalam hal ini pemerintah daerah berfungsi sebagai agen yang diberi kewenangan untuk menyajikan informasi yang bermanfaat bagi organisasi dan para pengguna informasi keuangan pemerintah sebagai prinsipal, baik secara langsung atau tidak langsung melalui wakil-wakilnya. Dalam hubungan keagenan, pemerintah sebagai agen harus melaksanakan apa yang menjadi kepentingan para pengguna informasi keuangan pemerintah sebagai prinsipal. Teori keagenan dalam penelitian ini juga dapat menjelaskan eksistensi pemerintah daerah sebagai suatu lembaga yang dapat dipercaya untuk bertindak sesuai dengan kepentingan publik dengan melaksanakan tugas dan fungsinya berupa penyajian laporan keuangan daerah yang tepat sesuai dengan standar akuntansi pemerintahan yang berlaku (Noreen, 1988).

\subsection{Penatausahaan Keuangan Daerah}

Bagian yang terpisahkan dari proses Pengelolaan Keuangan Daerah yaitu Penatausahaan Keuangan Daerah. Menurut Peraturan Pemerintah Republik Indonesia Nomor 58 Tahun 2005 tentang pengelolaan keuangan daerah dalam ketentuan umumnya menyatakan bahwa keuangan daerah adalah semua hak dan kewajiban daerah dalam rangka penyelenggaraan pemerintah daerah yang dapat dinilai dengan uang termasuk didalamnya segala bentuk kekayaan daerah tersebut. Pemerintah daerah selaku pengelola yang harus menyediakan informasi keuangan yang diperlukan secara akurat, relevan, tepat waktu, dan dapat dipercaya (Sipahutar, 2018). Untuk itu, pemerintah daerah dituntut untuk memiliki sistem informasi akuntansi yang handal (Bodnar \& Hopwood, 2006). Dengan semakin kuatnya tuntutan desentralisasi, pemerintah mengeluarkan satu paket undang-undang otonomi daerah yaitu Undang-Undang Nomor 22 Tahun 1999 (saat ini telah dirubah menjadi Undang-Undang Nomor 32 Tahun 2004) Tentang Pemerintah Daerah dan Undang- Undang Nomor 25 Tahun 1999 (saat ini telah dirubah menjadi Undang-Undang Nomor 33 Tahun 2004) tentang Perimbangan Keuangan antara Pusat dan Daerah (Indonesia, 2004). Pelimpahan wewenang dari pemerintah pusat kepada pemerintah daerah yang diatur dalam Undang-undang Nomor 22 Tahun 1999 perlu dibarengi dengan pelimpahan keuangan dari pemerintah pusat ke pemerintah daerah yang diatur dalam Undang-undang Nomor 25 Tahun 1999. Penerimaan Daerah dalam pelaksanaan desentralisasi menurut Undang-Undang Nomor 33 tahun 2004 Tentang Perimbangan keuangan Antara Pemerintah Pusat dan Daerah terdiri atas Pendapatan daerah dan Pembiayaan. Pendapatan daerah bersumber dari Pendapatan Asli Daerah, dana perimbangan, lain-lain pendapatan. Sedangkan pembiayaan bersumber dari sisa lebih perhitungan anggaran daerah, penerimaan pinjaman daerah, dana cadangan daerah, hasil penjualan kekayaan daerah yang dipisahkan.Berbagai peraturan pemerintah dan peraturan lain juga disesuaikan oleh Pemerintah. Pemerintah mengeluarkan PP Nomor 58 Tahun 2005 tentang Pengelolaan Keuangan Daerah dan Permendagri Nomor 13 Tahun 2006 tentang Pedoman Keuangan Daerah sebagai pengganti PP Nomor 105 Tahun 2000 dan Kepmedagri Nomor 29 Tahun 2002.

Permendagri No.29 Tahun 2002 adalah tentang pedoman pengurusan, pertanggungjawaban dan pengawasan keuangan daerah serta tata cara penyusunan anggaran pendapatan dan belanja daerah, pelaksanaan tata usaha keuangan daerah dan penyusunan anggaran dan pendapatan belanja daerah. Kepmendagri ini merupakan petunjuk teknis pelaksanaan PP Nomor 105 tahun 2000 pasal 14 di bidang pengelolaan keuangan daerah dalam rangka pelaksanaan transparansi dan akuntabilitas keuangan daerah. Permendagri No.13 Tahun 2006 adalah tentang pengelolaan keuangan daerah, azas umum dan struktur APBD, penyusunan rancangan APBD, penetapan APBD, penyusunan dan penetapan APBD bagi daerah yang belum memiliki DPRD, pelaksanaan APBD, perubahan APBD, pengelolaan kas, penatausahaan keuangan daerah, akuntansi keuangan daerah, pertanggungjawaban pelaksanaan APBD, pembinaan dan pengawasan pengelolaan keuangan daerah, kerugian daerah dan pengelolaan keuangan BLUD. Permendagri No.13 Tahun 2006 juga mengatur tentang prosedur akuntansi pada SKPD yang meliputi serangkaian proses mulai dari pencatatan, pengikhtisaran sampai dengan pelaporan keuangan dalam rangka pertanggungjawaban pelaksanaan APBD yang dapat dilakukan secara manual atau menggunakan aplikasi komputer. Permendagri ini juga mengatur tata cara pelaksanaan penerimaan daerah yang dikelola oleh bendahara penerimaan.

\subsection{Laporan Keuangan Pemerintah}

Pemerintah daerah sebagai pihak yang diserahi tugas menjalankan roda pemerintahan, pembangunan, dan layanan sosial masyarakat wajib menyampaikan laporan pertanggungjawaban 
keuangan daerahnya untuk dinilai apakah pemerintah daerah berhasil menjalankan tugasnya dengan baik atau tidak. Oleh karena itu, untuk mengetahui posisi dan kinerja pemerintah daerah dapat dilihat dalam laporan keuangannnya. Laporan keuangan merupakan laporan yang disusun secara sistematis mengenai posisi keuangan suatu entitas pada saat tertentu; dan kinerja suatu entitas pada periode tertentu (Aliyah, 2012). Tujuan umum laporan keuangan adalah menyajikan informasi mengenai posisi keuangan, realisasi anggaran, arus kas, dan kinerja keuangan suatu entitas pelaporan yang bermanfaat bagi para pengguna dalam membuat dan mengevaluasi keputusan mengenai alokasi sumber daya, secara spesifik, tujuan pelaporan untuk menunjukkan akuntabilitas entitas pelaporan atas sumber daya yang dipercayakan kepadanya, dengan menyediakan informasi mengenai posisi sumber daya ekonomi, kewajiban, dan ekuitas dana pemerintah, menyediakan informasi mengenai perubahan posisi sumber daya ekonomi, kewajiban, dan ekuitas pemerintah, menyediakan informasi mengenai sumber, alokasi, dan penggunaan sumber daya ekonomi, menyediakan informasi mengenai ketaatan realisasi terhadap anggarannya, menyediakan informasi mengenai cara entitas pelaporan mendanai aktivitasnya dan memenuhi keutuhan kasnya, menyediakan informasi mengenai potensi pemerintah untuk membiayai penyelenggaraan kegiatan pemerintah, menyediakan informasi yang berguna untuk mengevaluasi kemampuan entitas pelaporan dalam aktivitasnya.

Menurut PSAP 01 paragraf 13, tanggung jawab penyusunan dan penyajian laporan keuangan berada pada pimpinan entitas. Dalam lingkup pemerintah daerah yang dimaksud dengan pimpinan entitas adalah setiap kepala satuan kerja perangkat daerah (SKPD) pada sebagai entitas akuntansi dan setiap gubernur/bupati/walikota sebagai entitas pelaporan. Kewajiban dan tanggung jawab penyusunan dan penyajian laporan keuangan untuk setiap kepala SKPD juga dinyatakan dalam pasal 56 ayat (2) huruf a Undang-Undang Nomor 1 Tahun 2004 tentang Perbendaharaan Negara, yang berbunyi: "Kepala satuan perangkat daerah selaku pengguna anggaran/pengguna barang menyusun dan menyampaikan laporan keuangan yang meliputi laporan realisasi anggaran, neraca dan catatan atas laporan keuangan." Oleh karena itu, tanggung jawab penyusunan dan penyajian laporan keuangan berada pada pimpinan entitas.

Laporan keuangan berdasarkan Peraturan Pemerintah No 71 Tahun 2010 tentang Standar Akuntansi Pemerintahan terdiri dari: (1) Laporan Realisasi Anggaran (LRA), menyajikan ikhtisar sumber, alokasi dan pemakaian sumber daya ekonomi yang dikelola oleh Pemerintah Daerah, yang menggambarkan perbandingan antara realisasi dan anggarannya dalam satu periode pelaporan. Tujuan pelaporan realisasi anggaran adalah memberikan informasi tentang realisasi dan anggaran pemerintah daerah secara tersanding.Penyandingan antara anggaran dengan realisasinya menunjukkan tingkat ketercapaian target-target yang telah disepakati antara legislatif dengan eksekutif sesuai peraturan perundang-undangan. (2) Laporan Perubahan Saldo Anggaran Lebih (SAL), menyajikan informasi kenaikan atau penurunan Saldo Anggaran Lebih tahun Pelaporan di bandingkan dengan tahun sebelumnya. (3) Neraca, menggambarkan posisi keuangan suatu entitas pelaporan mengenai asset, kewajiban, dan ekuitas pada tanggal tertentu.Unsur yang dicakup oleh neraca terdiri dari asset, kewajiban dan ekuitas. Masing - masing unsur yaitu (a)Asset adalah sumber daya ekonomi yang dikuasai atau dimiliki oleh pemerintah sebagai akibat dari peristiwa masa lalu dan dari mana manfaat ekonomi atau social di masa depan diharapkan dapat diperoleh baik oleh pemerintah maupun masyarakat serta dapat di ukur dalam satuan uang. (b) Kewajiban adalah utang yang timbul dari peristiwa masa lalu yang penyelesaiannya mengakibatkan aliran keluar sumber daya ekonomi pemerintah. (c) Ekuitas adalah kekayaan bersih pemerintah yang merupakan selisih antara asset dan kewajiban pemerintah. (4) Laporan Arus Kas, menyajikan informasi kas sehubungan dengan aktivitas operasi, investasi, pendanaan dan transitoris yang menggambarkan saldo awal, penerimaan, pengeluaran, dan saldo akhir kas pemerintah pusat/daerah selama periode tertentu. Unsur yang dicakup dalam Laporan Arus Kas terdiri dari penerimaan dan pengeluaran kas,. Penerimaan kas adalah semua aliran kas yang masuk ke Bendahara Umum Negara / Daerah. Sedangkan pengeluaran kas adalah semua aliran kas yang keluar dari Bendahara Umum Negara / Daerah. (5) Laporan Operasional, menyajikan ikhtisar sumber daya ekonomi yang menambah ekuitas dan penggunaannya yang dikelola oleh pemerintah pusat/daerah untuk kegiatan penyelenggaraan pemerintahan dalam satu periode pelaporan. Unsur yang di cakup secara langsung dalam Laporan Operasional terdiri dari pendapatanLO, beban, transfer, dan pos-pos luar biasa. Pendapatan-LO adalah hak pemerintah yang di akui sebagai penambah nilai kekayaan bersih. Adapun beban adalah kewajiban pemerintah yang di akui sebagai pengurang nilai kekayaan bersih. Sedangkan transfer ialah hak penerimaan atau kewajiban 
pengeluaran uang dari/oleh suatu entitas pelaporan dari/kepada entitas pelaporan lain, termasuk dana perimbangan dan dana bagi hasil. Pos Luar Biasa adalah pendapatan luar biasa atau beban luar biasa yang terjadi karena kejadian atau transaksi yang bukan merupakan operasi biasa, tidak diharapkan sering atau rutin terjadi dan berada diluar kendali atau pengaruh entitas bersangkutan. (6)

Laporan Perubahan Ekuitas, menyajikan informasi kenaikan atau penurunan ekuitas tahun pelaporan dibandingkan tahun sebelumnya. (7) Catatan atas Laporan Keuangan, meliputi penjelasan naratif atau rincian dari angka yang tertera dalam Laporan Realisasi Anggaran, Laporan Perubahan SAL, Laporan Operasional, Laporan Perubahan Ekuitas, Neraca, dan Laporan Arus Kas, Catatan atas Laporan Keuangan juga mencakup informasi tentang kebijakan akuntansi yang dipergunakan oleh entitas pelaporan dan dan infomasi lain yang diharuskan dan di anjurkan untuk di ungkapkan di dalam Standar Akuntansi Pemerintahan serta ungkapan - ungkapan yang diperlukan untuk menghasilkan penyajian laporan keuangan secara wajar. Catatan atas Laporan Keuangan mengungkapkan / menyajikan / menyediakan hal-hal yaitu mengungkapkan informasi umum tentang entitas pelaporan dan entitas Akuntansi, menyajikan informasi tentang kebijakan fiscal/keuangan dan ekonomi makro, menyajikan ikhtisar pencapaian target keuangan selama tahun pelaporan berikut kendala dan hambatan yang di hadapi dalam pencapaian target, menyajikan informasi tentang dasar penyusunan laporan keuangan dan kebijakan-kebijakan akuntansi yang dipilih untuk diterapkan atas transaksi dan kejadian-kejadian penting lainnya, menyajikan rincian dan penjelasan masing-masing pos yang di sajikan pada lembar laporan keuangan, mengungkapkan informasi yang diharuskan oleh pernyataan Standar Akuntansi Pemerintahan yang belum disajikan dalam lembar muka laporan keuangan, menyediakan informasi lainnya yang diperlukan untuk penyajian yang wajar, yang tidak disajikan dalam lembar muka laporan keuangan.

\subsection{Standar Akuntansi Pemerintah}

Berdasarkan peraturan pemerintah nomor 71 tahun 2010 pasal 1 ayat (3) tentang standar akuntansi pemerintahan, standar akuntansi pemerintahan yang selanjutnya disingkat SAP, adalah prinsip-prinsip akuntansi yang diterapkan dalam menyusun dan menyajikan laporan keuangan pemerintah. Dapat disimpulkan bahwa SAP merupakan persyaratan yang mempunyai kekuatan hukum dalam upaya meningkatkan kualitas laporan keuangan pemerintah di Indonesia. Wijaya (2008), standar akuntansi pemerintahan (SAP) merupakan standar akuntansi pertama di Indonesia yang mengatur mengenai akuntansi pemerintahan Indonesia. Sehingga dengan adanya standar ini, maka laporan keuangan pemerintah yang merupakan hasil dari proses akuntansi diharapkan dapat digunakan sebagai alat komunikasi antara pemerintah dengan stakeholders sehingga tercipta pengelolaan keuangan negara yang transparan dan akuntabel. Fakhrurazi (2010) manfaat yang dapat diperoleh dengan adanya standar akuntansi pemerintahan adalah laporan keuangan yang dihasilkan dapat memberikan informasi keuangan yang terbuka, jujur, dan menyeluruh kepada stakeholders. Selain itu, dalam lingkup manajemen dapat memudahkan fungsi perencanaan, pengelolaan dan pengendalian atas aset, kewajiban, dan ekuitas dana pemerintah. Manfaat selanjutnya adalah keseimbangan antargenerasi di mana dapat memberikan informasi mengenai kecukupan penerimaan pemerintah untuk membiayai seluruh pengeluaran dan apakah generasi yang akan datang ikut menanggung beban pengeluaran tersebut. Laporan keuangan yang dihasilkan juga dapat mempertanggungjawabkan pengelolaan dan pelaksanaan kebijakan sumber daya dalam mencapai tujuan.

Dalam Standar Akuntansi Pemerintahan (SAP) yang terkandung dalam Peraturan Pemerintah No. 71 Tahun 2010 mengadopsi karakteristik kualitatif primer sebagaimana tercantum dalam SFAC No. 2. KSAP menekankan pada empat prasyarat normatif yakni (1) relevan, informasi yang termuat di dalamnya dapat mempengaruhi keputusan pengguna dengan membantu mereka mengevaluasi peristiwa masa lalu atau masa kini dan memprediksi masa depan, serta menegaskan atau mengoreksi hasil evaluasi mereka di masa lalu. Informasi yang relevan memiliki unsur-unsur berikut: (a) Manfaat umpan balik (feedback value). Informasi memungkinkan pengguna untuk menegaskan alat mengoreksi ekspektasi mereka di masa lalu. (b) Manfaat prediktif (predictive value). Informasi dapat membantu pengguna untuk memprediksi masa yang akan datang berdasarkan hasil masa lalu dan kejadian masa kini. (c) Tepat waktu (timeliness). Informasi yang disajikan secara tepat waktu dapat berpengaruh dan berguna dalam pengambilan keputusan. (d) Lengkap, yaitu mencakup semua informasi akuntansi yang dapat mempengaruhi pengambilan keputusan. Informasi yang melatarbelakangi setiap butir informasi utama yang termuat dalam laporan keuangan diungkapkan dengan jelas agar kekeliruan dalam 
penggunaan informasi tersebut dapat dicegah. (2) Andal, berupa informasi dalam laporan keuangan bebas dari pengertian yang menyesatkan dan kesalahan material, menyajikan setiap fakta secara jujur, serta dapat diverifikasi. Informasi yang andal memenuhi karakteristik berikut: (a) Penyajian jujur. Informasi menggambarkan dengan jujur transaksi serta peristiwa lainnya yang seharusnya disajikan atau secara wajar dapat diharapkan untuk disajikan. (b) Dapat diverifikasi (verifiability). Informasi yang disajikan dalam laporan keuangan dapat diuji, dan apabila pengujian dilakukan lebih dari sekali oleh pihak yang berbeda, hasilnya tetap menunjukkan simpulan yang tidak berbeda jauh. (c) Netralitas, yaitu informasi diarahkan pada kebutuhan umum dan tidak berpihak pada kebutuhan pihak tertentu. (3) Dapat dibandingkan, yaitu informasi yang termuat dalam laporan keuangan akan lebih berguna jika dapat dibandingkan dengan laporan keuangan periode sebelumnya atau laporan keuangan entitas pelaporan lain pada umumnya. (4) Dapat dipahami. Informasi yang disajikan dalam laporan keuangan dapat dipahami oleh pengguna dan dinyatakan dalam bentuk serta istilah yang disesuaikan dengan batas pemahaman para pengguna.

\subsection{Perbedaan PP No. 24 Tahun 2005 dengan PP No. 71 Tahun 2010}

Terdapat perbedaan antara PP No. 71 Tahun 2010 dengan PP-PP lain karena pada PP No. 71 Tahun 2010 terdapat 2 buah lampiran. Lampiran I merupakan Standar Akuntansi Pemerintah Berbasis Akrual yang dilaksanakan selambat-lambtanya mulai tahun 2014, sedangkan Lampiran II merupakan Standar Akuntansi Pemerintah Berbasis Kas Menuju Akrual yang hanya berlaku hingga tahun 2014. Lampiran I berlaku sejak tanggal ditetapkan dan dapat segera diterapkan oleh setiap entitas (strategi pentahapan pemberlakuan akan ditetapkan lebih lanjut oleh Menteri Keuangan dan Menteri Dalam Negeri), sedangkan Lampiran II berlaku selama masa transisi bagi entitas yang belum siap untuk menerapkan SAP Berbasis Akrual. Dengan kata lain, Lampiran II merupakan lampiran yang memuat kembali seluruh aturan yang ada pada PP 24 Tahun 2005 tanpa perubahan sedikit pun. Perbedaan antara PP 71 dengan PP 24 tahun 2005, utamanya terkait dengan komponen laporan keuangan, sebagai berikut:

Tabel 1. Perbedaan Komponen Laporan Keuangan

\begin{tabular}{|c|c|}
\hline PP 24 Tahun 2005 & PP 71 Tahun 2010 \\
\hline $\begin{array}{l}\text { Laporan Perubahan Saldo Anggaran Lebih (SAL) } \\
-\quad \text { Tidak Ada Perubahan }\end{array}$ & $\begin{array}{l}\text { Laporan Perubahan Saldo Anggaran Lebih (SAL) } \\
\text { - Perubahan SAL menyajikan secara komparatif dengan } \\
\text { periode sebelumnya : } \\
\text { 1. Saldo Anggaran Lebih awal, } \\
\text { 2. Penggunaan SAL } \\
\text { 3. Sisa Lebih Kurang Pembiayaan Anggaran tahun } \\
\text { berjalan } \\
\text { 4. Koreksi Kesalahan Pembukuan tahun Sebelumnya } \\
\text { 5. Lain-lain } \\
\text { 6. Saldo Anggaran Lebih Akhir. }\end{array}$ \\
\hline $\begin{array}{l}\text { Neraca } \\
\text { Ekuitas Dana terbagi : } \\
\text { 1. Ekuitas Dana Lancar selisih antara aset } \\
\text { lancar dan kewajiban jangka pendek, } \\
\text { termasuk sisa lebih pembiayaan } \\
\text { anggaran saldo anggaran lebih. } \\
\text { 2. Ekuitas Dana Investasi mencerminkan } \\
\text { kekayaan pemerintah yang tertanam } \\
\text { dalam investasi jangan panjang, aset } \\
\text { tetap, dan aset lainnya, dikurangi } \\
\text { dengan kewajiban jangka panjang. } \\
\text { 3. Ekuitas Dana Cadangan mencerminkan } \\
\text { kekayaan pemerintah yang } \\
\text { dicadangkan untuk tujuan tertentu } \\
\text { sesuai dengan peraturan perundang- } \\
\text { perundangan. }\end{array}$ & $\begin{array}{l}\text { Neraca } \\
\text { - Hanya ekuitas, yaitu kekayaan bersih pemerintah yang } \\
\text { merupakan selisih antara aset dan kewajiban } \\
\text { pemerintah pada tanggal laporan. } \\
\text { - Saldo ekuitas di Neraca berasal dan saldo akhir } \\
\text { ekuitaspada Laporan Perubahan Ekuitas. }\end{array}$ \\
\hline $\begin{array}{l}\text { Laporan Arus Kas } \\
\text { - Disajikan oleh unit yang mempunyai fungsi } \\
\text { perbendaharaan }\end{array}$ & $\begin{array}{l}\text { Laporan Arus Kas } \\
\text { - } \begin{array}{l}\text { Disajikan oleh unit yang mepunyai fungsi } \\
\text { perbendaharaan umum }\end{array}\end{array}$ \\
\hline
\end{tabular}




\begin{tabular}{|c|c|}
\hline PP 24 Tahun 2005 & PP 71 Tahun 2010 \\
\hline $\begin{array}{l}\text { Arus masuk dan keluar kas diklasifikasikan } \\
\text { berdasarkan aktivitas operasi, investasi, } \\
\text { aset non keuangan, pembiayaan dan non } \\
\text { anggaran. }\end{array}$ & $\begin{array}{l}\text { - Arus masuk dan keluar kas diklasifikasikan } \\
\text { berdasarkan aktivitas operasi, investasi, pendanaan dan } \\
\text { transitoris. }\end{array}$ \\
\hline $\begin{array}{l}\text { Laporan Kinerja Keuangan } \\
\text { Bersifat optional } \\
\text { - } \begin{array}{l}\text { Disusun oleh entitas pelaporan yang } \\
\text { menyajikan laporan berbasis akrual }\end{array} \\
\text { Sekurang-kurangnya menyajina pos-pos: } \\
\text { 1. Pendapatan dari kegiatan } \\
\text { operasional. } \\
\text { 2. Beban berdasarkan klasifikasi } \\
\text { fungsional dan klasifikasi } \\
\text { ekonomi. } \\
\text { 3. Surplus atau defisit. }\end{array}$ & $\begin{array}{l}\text { Laporan Operasional } \\
\text { - } \quad \text { Merupakan laporan keuangan pokok } \\
\text { Menyajikan pos-pos berikut: } \\
\text { 1. Pendapatan-LO dari kegiatan operasional. } \\
\text { 2. Beban dari kegiatan operasional. } \\
\text { 3. Surplus/defisit dari kegiatan non } \\
\begin{array}{l}\text { operasional bila ada pos luar biasa, bila } \\
\text { ada surplus/defisit-LO. }\end{array}\end{array}$ \\
\hline 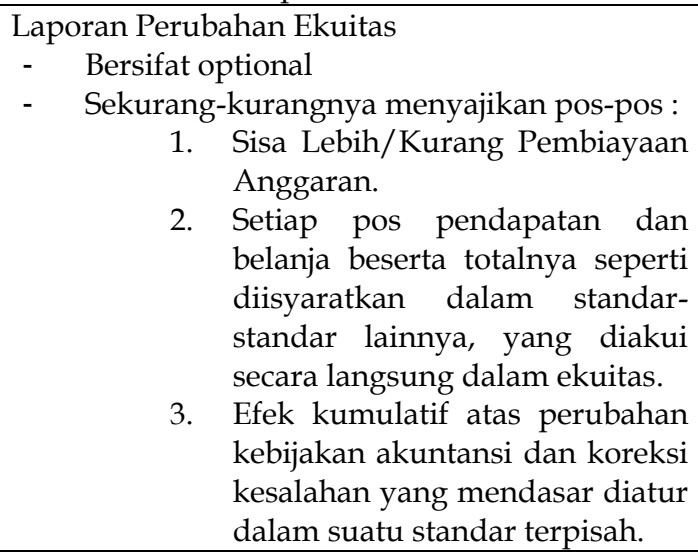 & 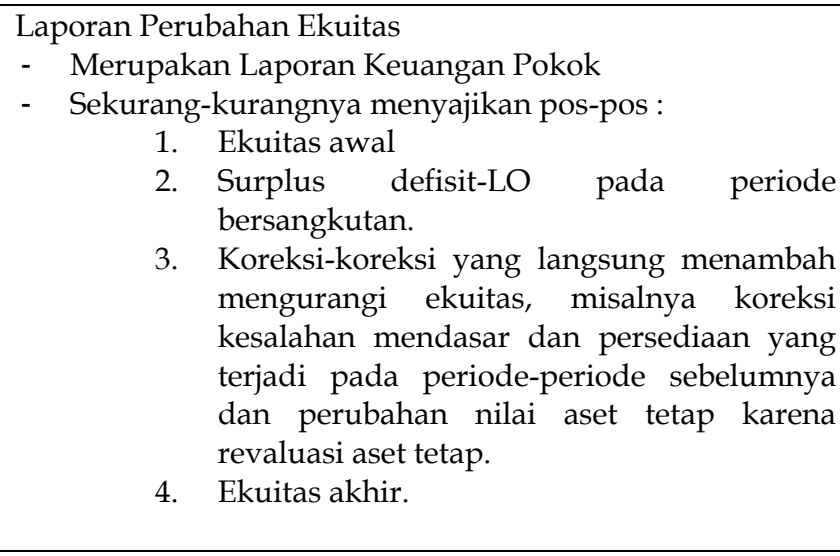 \\
\hline $\begin{array}{l}\text { CALK } \\
\text { - Pada dasarnya hampir sama dengan PP } \\
\text { baru. }\end{array}$ & $\begin{array}{l}\text { CALK } \\
\text { - } \quad \text { Perbedaan yang muncul hanya dikarenakan komponen } \\
\quad \text { laporan keuangan yang berbeda dengan PP lama. }\end{array}$ \\
\hline
\end{tabular}

\subsection{Faktor Pendukung dalam Penyajian Laporan Keuangan Pemerintah Daerah}

Penyajian Laporan Keuangan daerah memerlukan faktor pendukung berupa Sumber Daya Manusia dan Perangkat pendukung teknis. Dalam penyusuna dan penyajian (e.g., Kiranayanti \& Erawati, 2016) menyatakan bahwa kapasitas SDM adalah kemampuan seseorang atau individu, suatu organisasi (kelembagaan), atau suatu sistem untuk melaksanakan fungsi-fungsi atau kewenangannya untuk mencapai tujuannya secara efektif dan efisien. Kemampuan seseorang atau individu dalam suatu organisasi atau kelembagaan dapat dilihat dari pencapaian tujuan dan efektifitas serta efisiensi kinerja sehingga menghasilkan suatu keluaran (outputs) dan hasil (outcomes). Alimbudiono \& Andono (2004) menyatakan bahwa untuk menilai kapasitas dan kualitas sumber daya manusia dalam melaksanakan suatu fungsi, termasuk akuntansi, dapat dilihat dari level of responsibility dan kompetensi sumber daya tersebut. Tanggung jawab dapat dilihat dalam deskripsi jabatan. Deskripsi jabatan merupakan dasar untuk melaksanakan tugas dengan baik. Tanpa adanya deskripsi jabatan yang jelas, sumber daya tersebut tidak dapat melaksanakan tugasnya dengan baik. Sedangkan kompetensi dapat dilihat dari latar belakang pendidikan, pelatihan-pelatihan dan dari keterampilan yang dinyatakan dalam pelaksanaan tugas. Kompetensi merupakan suatu karakteristik dari seseorang yang memiliki keterampilan (skill), pengetahuan (knowledge) dan kemampuan (ability) untuk melaksanakan suatu pekerjaan (Rina et al., 2017).

Perangkat pendukung teknis, erangkat utama yang dibutuhkan dalam penyusunan dan penyajian laporan keuangan adalah perangkat pendukung teknis. Perangkat pendukung teknis adalah perangkat keras (hardware) berupa unit komputer. Laudon (2007) menyatakan bahwa perangkat keras adalah perlengkapan fisik yang digunakan untuk aktifitas input, pemrosesan dan output dalam sebuah sistem informasi. Sedangkan perangkat lunak adalah sekumpulan rincian instruksi program yang mengendalikan dan mengkoordinasi perangkat keras komponen komputer di dalam sebuah sistem 
informasi. Perangkat lunak (software) yang digunakan adalah aplikasi khusus yang dinamakan program Sistem Akuntansi Pemerintah Daerah dan selanjutnya secara otomatis mempersiapkan laporan keuangan daerah ketika laporan tersebut dibutuhkan. Pemerintah daerah akan menyusun laporan keuangan daerah mengacu pada standar akuntansi yang berlaku umum yaitu Standar Akuntansi Pemerintahan.

\subsection{Penelitian Terdahulu}

Tabel 2. Matriks Peneliti Terdahulu

\begin{tabular}{|c|c|c|c|}
\hline No & Penelitian & Judul & Hasil Penelitian \\
\hline 1 & (Kema, 2013) & $\begin{array}{llr}\text { Penyajian } & \text { Laporan } & \text { Keuangan } \\
\text { Berdasarkan } & \text { SAP pada } & \text { Pemerintah } \\
\text { Kota Manado } & & \\
\end{array}$ & $\begin{array}{l}\text { Pemerintah Kota Manado Tahun } 2011 \\
\text { dalam penyajian laporan keuangan belum } \\
\text { mengacu pada SAP }\end{array}$ \\
\hline 2 & $\begin{array}{l}\text { (Ningtyas et al., } \\
\text { 2015) }\end{array}$ & $\begin{array}{l}\text { Evaluasi penerapan PP No. } 71 \text { Tahun } \\
2010 \text { pada Dinas Energi dan Sumber } \\
\text { Daya Mineral Provinsi Sulawsi Utara }\end{array}$ & $\begin{array}{l}\text { Penyajian Laporan Keuangan DESDM } \\
\text { Provinsi Sulawesi Utara Tahun } 2013 \\
\text { belum menerapkan PP tahun } 2010 \text { tapi } \\
\text { telah berpedoman pada PP No. } 24 \text { tahun } \\
2005 \text {. }\end{array}$ \\
\hline 3 & $\begin{array}{l}\text { (Bustamam et } \\
\text { al., 2015) }\end{array}$ & $\begin{array}{l}\text { Analisis penyajian laporan keuangan } \\
\text { syariah pada Baitul Mal Aceh }\end{array}$ & $\begin{array}{l}\text { Baitu Mal Aceh telah menerapkan sistem } \\
\text { pelaporan sesuai standar akuntansi } \\
\text { keuangan yaitu PSAK } 109\end{array}$ \\
\hline 4 & $\begin{array}{l}\text { (Mentu \& } \\
\text { Sondakh, 2016) }\end{array}$ & $\begin{array}{l}\text { Penyajian Laporan Keuangan Sesuai } \\
\text { Peraturan Pemerintah No. } 71 \text { tentang } \\
\text { Satndar Akuntansi Pemerintahan pada } \\
\text { Dinas Pendapatan Daerah dan Dinas } \\
\text { Sosial Provinsi Sulawesi Utara }\end{array}$ & $\begin{array}{l}\text { Dinas Pendapatan Daearah dan Dinas } \\
\text { Sosial Provinsi Sulawesi Utara pada tahun } \\
2014 \text { dan } 2015 \text { belum sesuai dengan PP } \\
\text { No. } 71 \text { tahun } 2010 \text {. }\end{array}$ \\
\hline 5 & $\begin{array}{l}\text { (Satrio et al., } \\
\text { 2016) }\end{array}$ & 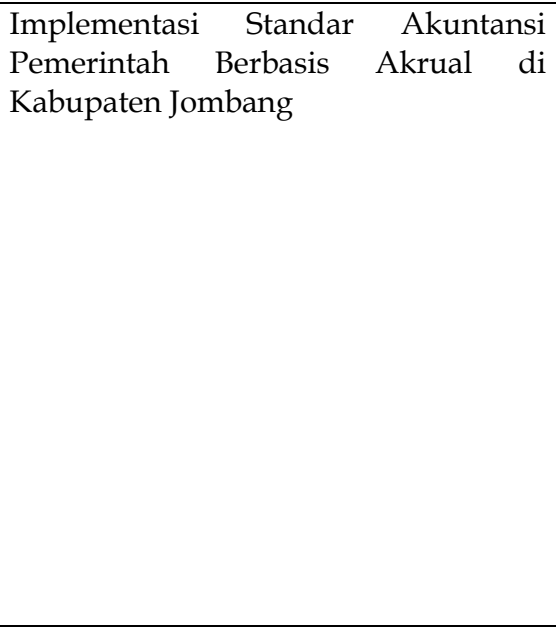 & $\begin{array}{l}\text { pimpinan beserta jajaran SKPD memiliki } \\
\text { komitmen dalam implementasi SAP } \\
\text { berbasis akrual. Perangkat regulasi dan } \\
\text { kebijakan juga telah dibuat, } \\
\text { disosialisasikan dan diimplementasikan. } \\
\text { Dalam pengelolaan SDM telah dilakukan } \\
\text { sosialisasi dan pelatihan bagi pengelola } \\
\text { keuangan SKPD. Sedangkan dalam } \\
\text { pengelolaan teknologi informasi } \\
\text { Pemerintah Kabupaten Jombang telah } \\
\text { bekerja sama dengan BPKP dalam } \\
\text { penyediaan aplikasi keuangan SIMDA. } \\
\text { Namun dari ketiga aspek tersebut masih } \\
\text { terdapat kendala-kendala yang perlu } \\
\text { mendapat perhatian Pemerintah } \\
\text { Kabupaten Jombang. }\end{array}$ \\
\hline
\end{tabular}

\subsection{Kerangka Konseptual}

Berdasarkan kajian pustaka yang telah dilakukan, selanjutnya dikembangkan suatu kerangka pemikiran sesuai dengan isu dan tujuan penelitian. Penelitian ini juga menggunakan agency theory sebagai Grand Theory untuk menjelaskan hubungan keagenan dimana pemerintah sebagai agen harus melaksanakan apa yang menjadi kepentingan para pengguna informasi keuangan pemerintah sebagai principal salah satunya masyarakat. Teori keagenan dalam penelitian ini juga dapat menjelaskan eksistensi pemerintah daerah sebagai suatu lembaga yang dapat dipercaya untuk bertindak sesuai dengan kepentingan publik dengan melaksanakan tugas dan fungsinya berupa penyajian laporan keuangan daerah yang tepat sesuai dengan standar akuntansi pemerintahan yang berlaku. Dalam proses pengelolaan keuangan daerah, bendahara penerimaan yang bertugas menyelenggarakan pembukuan terhadap seluruh penerimaan dan penyetoran atas penerimaan dan Bendahara pengeluaran yang bertugas mengelola uang persediaan, menerima, menyimpan, menatausahakan dan membukukan uang dalam pengelolaannya melakukan penatausahaan untuk melaksanakan tugastugas kebendaharaan pada Organisasi Perangkat Daerah (OPD).

Laporan-laporan pendapatan, belanja serta kekayaan dan kewajiban daerah disusun berdasarkan Sistem Akuntansi Pemerintah Daerah yang mengacu kepada Standar Akuntansi Pemerintahan (SAP). 
Sistem akuntansi inilah yang menghasilkan laporan keuangan daerah. Laporan Keuangan Daerah merupakan ringkasan dari suatu proses pencatatan, suatu ringkasan dari transaksi keuangan yang terjadi selama satu tahun buku yang bersangkutan (Baridwan, 2000). Laporan Keuangan Pemerintah Daerah dituntut untuk dapat menyajikan laporan keuangan yang meliputi: Laporan Realisasi Anggaran, Neraca Daerah, Laporan Aliran Kas, Catatan Atas Laporan Keuangan dan Laporan Realisasi Anggaran. Pemerintah menerbitkan Peraturan Pemerintah No.71 Tahun 2010 tentang SAP Berbasis Akrual dimana SAP mengakui pendapatan, beban, aset, utang dan ekuitas dalam pelaporan finansial berbasis akrual. Selain itu, juga mengakui pendapatan, belanja dan pembiayaan dalam pelaporan pelaksanaan anggaran basis akural yang ditetapkan dalam APBN/APBD. PP nomor 71 Tahun 2010 yang telah membawa perubahan besar dan memberikan pendekatan baru dalam pengelolaan keuangan daerah membutuhkan faktor pendukung diantaranya Sumber daya manusia yang kompeten dan perangkat pendukung teknis. Sumber daya manusia yang kompeten yaitu tenaga-tenaga akuntansi terampil pada pemerintah daerah dibutuhkan untuk menyusun dan menyajikan laporan keuangan daerah sesuai dengan SAP. Tidak hanya tenaga-tenaga akuntansi terampil tersebut, juga dibutuhkan adanya sistem dan prosedur pembukuan yang memadai yang didukung oleh perangkat teknis berupa komputer.Berdasarkan uraian di atas, dapat dilihat kerangka konseptual penelitian ini pada gambar 1 berikut:

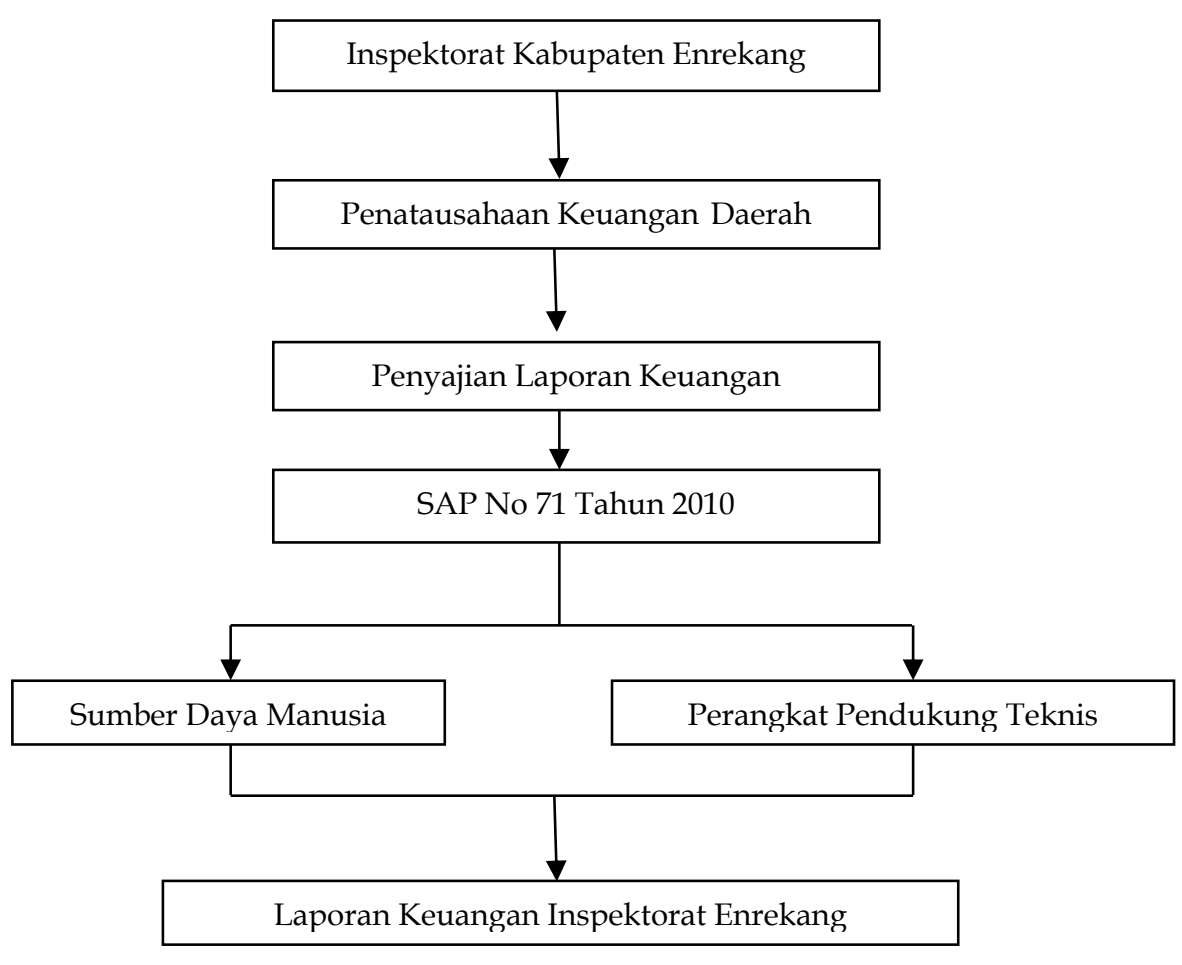

Gambar 1: Kerangka Konseptual

\section{Metode Penelitian}

Pendekatan penelitian ini menggunakan pendekatan deskriptif. Metode deskriptif adalah metode yang digunakan untuk menggambarkan atau menganalisa suatu hasil penelitian tetapi tidak digunakan untuk membuat kesimpulan yang lebih luas (Sugiyono, 2011; Chamidah et al., 2020). Lokasi yang dijadikan tempat penelitian adalah Inspektorat Kabupaten Enrekang. Adapun waktu yang diperlukan adalah 2 (dua) bulan yaitu September 2020 sampai dengan November 2020. Jenis data penelitian adalah data sekunder berupa informasi keuangan yang terdapat dalam laporan keuangan Inspektorat Kabupaten Enrekang. Sedangkan sumber data dari penelitian ini adalah data sejarah singkat Inspektorat Kabupaten Enrekang, struktur organisasi dan data informasi yang berhubungan dengan 
penyajian laporan keuangan. Teknik pengumpulan data yang digunakan peneliti dalam pengumpulan data yaitu: (1) Teknik wawancara, yaitu melakukan tanya jawab langsung secara lisan dengan beberapa pihak yang berkompeten dan berwenang dalam memberikan data yang dibutuhkan sehubungan dengan analisis penyajian laporan keuangan pada Inspektorat Kabupaten Enrekang. (2) Teknik dokumentasi, yaitu melakukan penghimpunan atas data-data sekunder untuk mendapatkan data yang mendukung penelitian ini, seperti laporan realisasi anggaran, neraca, laporan arus kas dan catatan atas laporan keuangan. (3) Analisis dan pengolahan data, dengan menggabungkan data yang diperoleh dari teknik wawancara dan teknik dokumentasi dengan landasan teori hasil studi kepustakaan, kemudian ditarik kesimpulan dan diberikan saran-saran untuk perbaikan-perbaikan.

Metode analisis data dalam penelitian ini menggunakan metode deskriptif yaitu dengan mengumpulkan, mengolah dan menginterpretasikan data yang diperoleh sehingga memberi keterangan yang benar dan lengkap untuk pemecahan masalah yang dihadapi dan Model Analisis Data Kualitatif. (Miles \& Huberman, 1984). Miles dan Huberman (1984) mengemukakan bahwa aktivitas dalam analisis data kualitatif dilakukan secara interaktif dan berlangsung secara terus menerus sampai tuntas, sehingga datanya jenuh. Aktivitas dalam analisis data yaitu : data reduction, data display dan conclusion. (1) Data Reduction (Reduksi Data), data yang diperoleh dilapangan jumlahnya cukup banyak, untuk itu perlu dicatat secara teliti dan rinci. Mereduksi data berarti : merangkum, memilih hal-hal yang pokok, memfokuskan pada hal-hal yang penting, dicari tema dan polanya dan membuang yang tidak perlu. Data yang telah direduksi akan memberikan gambaran yang jelas dan mempermudah peneliti untuk melakukan pengumpulan data selanjutnya, dan mencarinya bila diperlukan. Reduksi data bisa dibantu dengan alat elektronik seperti : komputer, dengan memberikan kode pada aspekaspek tertentu. Dengan reduksi, maka peneliti merangkum, mengambil data yang penting, membuat kategorisasi, berdasarkan huruf besar, huruf kecil dan angka. Data yang tidak penting dibuang. (2) Data Display, setelah data direduksi, maka langkah berikutnya adalah mendisplay-kan data. Display data dalam penelitian kualitatif bisa dilakukan dalam bentuk : uraian singkat, bagan, hubungan antar kategori, flowchart dan sebagainya. Miles dan Huberman (1984) menyatakan bahwa yang paling sering digunakan untuk menyajikan data dalam penelitian kualitatif dengan teks yang bersifat naratif. Selain dalam bentuk naratif, display data dapat juga berupa grafik, matriks dan network (jejaring kerja).

Definisi operasional dalam penelitian ini adalah sebagai berikut: (1) Penatausahaan Keuangan Daerah adalah bagian dari proses pengelolaan keuangan daerah berupa asas dan pelaksanaan keuangan daerah yang berperan dalam meningkatkan efektifitas pelaksanaan APBD. (2) Laporan keuangan daerah adalah informasi keuangan dari entitas pemerintah daerah dalam rangka pertanggungjawaban pengelolaan keuangan daerah dan pengambilan keputusan ekonomi oleh pihakpihak yang membutuhkan. (3) Sumber daya manusia adalah kemampuan dari pegawai atau tenagatenaga bidang akuntansi untuk melaksanakan tugasnya dalam penyusunan dan penyajian laporan keuangan daerah. (4) Perangkat pendukung tehnis adalah ketersediaan perangkat pendukung berupa komputer yang membantu pegawai menyelesaikan tugasnya dalam penyusunan dsn penyajian laporan keuangan daerah.

\section{Hasil Penelitian dan Pembahasan}

\subsection{Analisa Laporan Realisasi Anggaran}

Laporan realisasi anggaran Inspektorat Kabupaten Enkrekang mengungkapkan kegiatan keuangan Pemerintah yang menunjukkan ketaatan terhadap APBD. Dalam hal ini disajikan informasi mengenai perhitungan atas pelaksanaan kegiatan yang telah dianggarkan dalam satu tahun anggaran meliputi pendapatan, belanja dan pembiayaan. Pendapatan diklasifikasikan berdasarkan pendapatan asli daerah, pendapatan transfer dan lain-lain pendapatan yaneg sah. Belanja terdiri dari belanja operasi, belanja modal, belanja tidak terduga dan transfer. Kemudian terdapat pula pos surplus/defisit yang memuat informasi mengenai selisih lebih/kurang antara pendapatan dan belanja selama satu periode pelaporan. Klasifikasi untuk pemubiayaan berdasarkan penerimaan daerah, pengeluaran daerah, pembiayaan neto. Terakhir pos sisa lebih pembiayaan anggaran (SILPA) yang berisi informasi selisih lebih antara realisasi penerimaan dan pengeluaran selama satu periode pelaporan. Adapun Laporan realisasi anggaran Inspektorat Kabupaten Enrekang yang menyajikan target dan realisasi anggaran tahun 2019 adalah sebagai berikut: 
Tabel 3. Laporan Realisasi Anggaran Pendapatan Dan Belanja Daerah Untuk Tahun Yang Berakhir Sampai Dengan 31 Desember 2019

\begin{tabular}{|c|c|c|c|c|}
\hline U R A I A N & $\begin{array}{l}\text { ANGGARAN } \\
2019\end{array}$ & $\begin{array}{l}\text { REALISASI } \\
2019\end{array}$ & $(\%)$ & $\begin{array}{l}\text { REALISASI } \\
2018\end{array}$ \\
\hline PENDAPATAN - LRA & 0,00 & 0,00 & 0.00 & 0,00 \\
\hline $\begin{array}{l}\text { PENDAPATAN ASLI DAERAH } \\
\text { (PAD) - LRA }\end{array}$ & 0,00 & 0,00 & 0.00 & 0,00 \\
\hline $\begin{array}{l}\text { Pendapatan Pajak Daerah - LRA } \\
\text { Pendapatan Retribusi Daerah - } \\
\text { LRA }\end{array}$ & 0,00 & 0,00 & 0.00 & 0,00 \\
\hline $\begin{array}{lrr}\text { Pendapatan } & \text { Hasil } & \text { Pengelolaan } \\
\text { Kekayaan } & \text { Daerah } & \text { yang } \\
\text { Dipisahkan - LRA } & \\
\end{array}$ & 0,00 & 0,00 & 0.00 & 0,00 \\
\hline Lain-lain PAD Yang Sah - LRA & 0,00 & 0,00 & 0.00 & 0,00 \\
\hline $\begin{array}{l}\text { PENDAPATAN TRANSFER - } \\
\text { LRA }\end{array}$ & 0,00 & 0,00 & 0.00 & 0,00 \\
\hline $\begin{array}{l}\text { Pendapatan Transfer Pemerintah } \\
\text { Pusat-Dana Perimbangan - LRA }\end{array}$ & 0,00 & 0,00 & 0.00 & 0,00 \\
\hline $\begin{array}{l}\text { Pendapatan Transfer Pemerintah } \\
\text { Pusat - Lainnya - LRA }\end{array}$ & 0,00 & 0,00 & 0.00 & 0,00 \\
\hline $\begin{array}{l}\text { Pendapatan Transfer Pemerintah } \\
\text { Daerah Lainnya - LRA }\end{array}$ & 0,00 & 0,00 & 0.00 & 0,00 \\
\hline Bantuan Keuangan - LRA & 0,00 & 0,00 & 0.00 & 0,00 \\
\hline $\begin{array}{ll}\text { LAIN-LAIN } & \text { PENDAPATAN } \\
\text { DAERAH YANG SAH }\end{array}$ & 0,00 & 0,00 & 0.00 & 0,00 \\
\hline Pendapatan Hibah - LRA & 0,00 & 0,00 & 0.00 & 0,00 \\
\hline Dana Darurat - LRA & 0,00 & 0,00 & 0.00 & 0,00 \\
\hline Pendapatan Lainnya - LRA & 0,00 & 0,00 & 0.00 & 0,00 \\
\hline JUMLAH PENDAPATAN & 0,00 & 0,00 & 0.00 & 0,00 \\
\hline \multicolumn{5}{|l|}{ BELANJA } \\
\hline BELANJA OPERASI & 8.339.109.290,00 & 8.292.980.227,00 & 99,45 & $8.480 .284 .042,00$ \\
\hline Belanja Pegawai & $3.927 .497 .790,00$ & $3.947 .403 .687,00$ & 99,37 & $4.096 .064 .117,00$ \\
\hline Belanja Barang dan Jasa & $4.366 .611 .500,00$ & $4.345 .567 .540,00$ & 99,52 & $4.384 .219 .925,00$ \\
\hline Belanja Bunga Belanja & 0,00 & 0,00 & 0.00 & 0,00 \\
\hline Subsidi Belanja Hibah & 0,00 & 0,00 & 0.00 & 0,00 \\
\hline Belanja Bantuan Sosial & 0,00 & 0,00 & 0.00 & 0,00 \\
\hline $\begin{array}{l}\text { Belanja Bagi Hasil Pajak dan } \\
\text { Retribusi }\end{array}$ & 0,00 & 0,00 & 0.00 & 0,00 \\
\hline BELANJA MODAL & $60.043 .500,00$ & $60.043 .500,00$ & 100,00 & $34.023 .000,00$ \\
\hline \multicolumn{5}{|l|}{ Belanja Modal Tanah } \\
\hline Belanja Modal Peralatan dan Mesin & $60.043 .500,00$ & $60.043 .500,00$ & 100,00 & $34.023 .000,00$ \\
\hline $\begin{array}{l}\text { Belanja Modal Gedung dan } \\
\text { Bangunan }\end{array}$ & 0,00 & 0,00 & 0.00 & 0,00 \\
\hline $\begin{array}{l}\text { Belanja Modal Jalan, Irigasi dan } \\
\text { Jaringan }\end{array}$ & 0,00 & 0,00 & 0.00 & 0,00 \\
\hline Belanja Modal Aset Tetap Lainnya & 0,00 & 0,00 & 0.00 & 0,00 \\
\hline Belanja Modal Operasional BLUD & 0,00 & 0,00 & 0.00 & 0,00 \\
\hline BELANJA TAK TERDUGA & 0,00 & 0,00 & 0.00 & 0,00 \\
\hline Belanja Tak Terduga & 0,00 & 0,00 & 0.00 & 0,00 \\
\hline JUMLAH BELANJA & $8.399 .152 .790,00$ & 8.353.023.727,00 & 99.45 & 8.514.307.042,00 \\
\hline TRANSFER & & & & \\
\hline
\end{tabular}




\begin{tabular}{|c|c|c|c|c|}
\hline $\begin{array}{lll}\text { TRANSFER } & \text { BAGI } & \text { HASIL } \\
\text { PENDAPATAN } & & \\
\end{array}$ & 0,00 & 0,00 & 0.00 & 0,00 \\
\hline Transfer Bagi Hasil Pajak Daerah & 0,00 & 0,00 & 0.00 & 0,00 \\
\hline $\begin{array}{l}\text { Transfer Bagi Hasil Pendapatan } \\
\text { Lainnya }\end{array}$ & 0,00 & 0,00 & 0.00 & 0,00 \\
\hline $\begin{array}{ll}\text { TRANSFER } & \text { BANTUAN } \\
\text { KEUANGAN } & \end{array}$ & 0,00 & 0,00 & 0.00 & 0,00 \\
\hline $\begin{array}{l}\text { Transfer Bantuan Keuangan ke } \\
\text { Pemerintah Daerah Lainnya }\end{array}$ & 0,00 & 0,00 & 0.00 & 0,00 \\
\hline $\begin{array}{l}\text { Transfer Bantuan Keuangan ke } \\
\text { Desa }\end{array}$ & 0,00 & 0,00 & 0.00 & 0,00 \\
\hline $\begin{array}{lll}\text { Transfer } & \text { Bantuan } & \text { Keuangan } \\
\text { Lainnya } & & \\
\end{array}$ & 0,00 & 0,00 & 0.00 & 0,00 \\
\hline Transfer Dana Otonomi Khusus & 0,00 & 0,00 & 0.00 & 0,00 \\
\hline SURPLUS / DEFISIT & $(8,399,152,790.00)$ & $(8,353,023,727.00)$ & & $(8,514,307,042.00)$ \\
\hline \multicolumn{5}{|l|}{ PEMBIAYAAN } \\
\hline PENERIMAAN PEMBIAYAAN & 0,00 & 0,00 & 0.00 & 0,00 \\
\hline Penggunaan SiLPA & 0,00 & 0,00 & 0.00 & 0,00 \\
\hline Pencairan Dana Cadangan & 0,00 & 0,00 & 0.00 & 0,00 \\
\hline $\begin{array}{l}\text { Hasil Penjualan Kekayaan Daerah } \\
\text { yang Dipisahkan }\end{array}$ & 0,00 & 0,00 & 0.00 & 0,00 \\
\hline Pinjaman Dalam Negeri & 0,00 & 0,00 & 0.00 & 0,00 \\
\hline $\begin{array}{l}\text { Penerimaan Kembali Investasi Non } \\
\text { Permanen Lainnya }\end{array}$ & 0,00 & 0,00 & 0.00 & 0,00 \\
\hline Pinjaman Luar Negeri & 0,00 & 0,00 & 0.00 & 0,00 \\
\hline $\begin{array}{l}\text { Penerimaan Utang Jangka Panjang } \\
\text { Lainnya }\end{array}$ & 0,00 & 0,00 & 0.00 & 0,00 \\
\hline Jumlah Penerimaan & 0,00 & 0,00 & 0.00 & 0,00 \\
\hline PENGELUARAN PEMBIAYAAN & 0,00 & 0,00 & 0.00 & 0,00 \\
\hline Pembentukan Dana Cadangan & 0,00 & 0,00 & 0.00 & 0,00 \\
\hline $\begin{array}{l}\text { Penyertaan Modal/Investasi } \\
\text { Pemerintah Daerah }\end{array}$ & 0,00 & 0,00 & 0.00 & 0,00 \\
\hline $\begin{array}{lll}\text { Pembayaran Pokok Pinjaman } \\
\text { Dalam Negeri }\end{array}$ & 0,00 & 0,00 & 0.00 & 0,00 \\
\hline Pemberian Pinjaman Daerah & 0,00 & 0,00 & 0.00 & 0,00 \\
\hline $\begin{array}{l}\text { Pengeluaran Investasi Non } \\
\text { Permanen Lainnya }\end{array}$ & 0,00 & 0,00 & 0.00 & 0,00 \\
\hline $\begin{array}{l}\text { Pembayaran Pokok Pinjaman Luar } \\
\text { Negeri }\end{array}$ & 0,00 & 0,00 & 0.00 & 0,00 \\
\hline $\begin{array}{l}\text { Pembayaran Utang Jangka Panjang } \\
\text { Lainnya }\end{array}$ & 0,00 & 0,00 & 0.00 & 0,00 \\
\hline $\begin{array}{l}\text { Pembayaran Piutang Pada Pihak } \\
\text { Ketiga }\end{array}$ & 0,00 & 0,00 & 0.00 & 0,00 \\
\hline Jumlah Pengeluaran & 0,00 & 0,00 & 0.00 & 0,00 \\
\hline PEMBIAYAAN NETTO & 0,00 & 0,00 & 0.00 & 0,00 \\
\hline $\begin{array}{l}\text { SISA LEBIH } \\
\text { ANGGARAN }\end{array}$ & $(8,399,152,790.00)$ & $(8,353,023,727.00)$ & & $(8,514,307,042.00)$ \\
\hline
\end{tabular}

Sumber : Laporan Keuangan Inspektorat Kab. Enrekang T.A 2019

Berdasarkan laporan realisasi anggaran Inspektorat Kabupaten Enrekang tahun 2019 di atas dapat dilihat bahwa jumlah belanja yang dianggarkan sebesar Rp. 8.399.152.790,00 dengan realisasinya sebesar Rp.8.353.023.727,00, yang terdiri dari belanja operasi sebesar Rp.8.292.980.227,00 dan belanja modal sebesar Rp. 60.043.500,00. Meskipun dana yang dianggarkan tidak dapat direalisasi sepenuhnya, tapi Inspektorat Kabupaten Enrekang sudah dapat menyajikan Laporan Realisasi Anggaran dengan baik. Berikut ringkasan penyajian Laporan Realisasi Anggaran Inspektorat Kabupaten Enrekang. 
Tabel 4. Ringkasan penyajian Laporan Realisasi Anggaran Inspektorat Kabupaten Enrekang

\begin{tabular}{|c|c|c|c|c|c|}
\hline No & Unsur & PP No.71 tahun 2010 & $\begin{array}{c}\text { LRA Inspektorat } \\
\text { Kabupaten Enrekang } 2019\end{array}$ & Sama & Berbeda \\
\hline 1 & $\begin{array}{l}\text { Penyajian } \\
\text { informasi realisasi } \\
\text { pendapatan, } \\
\text { belanja, transfer, } \\
\text { surplus/defisit } \\
\text { dan pembiayaan. }\end{array}$ & $\begin{array}{l}\text { PSAP } 02 \text { paragraf 9: laporan } \\
\text { realisasi anggaran menyajikan } \\
\text { informasi realisasi } \\
\text { pendapatan-LRA, belanja, } \\
\text { transfer, surplus/defisit dan } \\
\text { pembiayaan yang masing- } \\
\text { masing diperbandinglan } \\
\text { dengan anggarannya dalam } \\
\text { satu periode. }\end{array}$ & $\begin{array}{l}\text { Laporan realisasi anggaran } \\
\text { menyajikan informasi realisasi } \\
\text { pendapatan-LRA, belanja, } \\
\text { transfer, surplus/defisit dan } \\
\text { pembiayaan yang masing- } \\
\text { masing diperbandinglan } \\
\text { dengan anggarannya dalam } \\
\text { satu periode. }\end{array}$ & $\sqrt{ }$ & \\
\hline 2 & $\begin{array}{l}\text { Penyajian } \\
\text { informasi nama } \\
\text { entitas atau } \\
\text { sarana } \\
\text { identifikasi } \\
\text { lainnya, cakupan } \\
\text { entitas pelaporan, } \\
\text { Periode yang } \\
\text { dicakup, mata } \\
\text { uang pelaporandan } \\
\text { Satuan angka } \\
\text { yang digunakan. }\end{array}$ & $\begin{array}{l}\text { PSAP 02 Paragraf 10: Laporan } \\
\text { realisasi anggaran harus } \\
\text { diidentifikasi secara jelas, dan } \\
\text { diulang pada setiap nomor } \\
\text { halaman laporan, jika } \\
\text { dianggap perlu, informasi } \\
\text { berikut: } \\
\text { a) Nama entitas atau } \\
\text { sarana identifikasi } \\
\text { lainnya. } \\
\text { b) Cakupan entitas } \\
\text { pelaporan. } \\
\text { c) Periode } \\
\text { dicakup. yang } \\
\text { d) Mata } \\
\text { pelaporan. uang } \\
\text { e) Satuan angka yang } \\
\text { digunakan. }\end{array}$ & $\begin{array}{l}\text { Laporan realisasi anggaran } \\
\text { harus diidentifikasi secara } \\
\text { jelas, dan diulang pada setiap } \\
\text { nomor halaman laporan, jika } \\
\text { dianggap perlu, informasi } \\
\text { berikut: } \\
\text { a) Nama entitas atau } \\
\text { sarana identifikasi } \\
\text { lainnya. } \\
\text { b) Cakupan entitas } \\
\text { pelaporan. } \\
\text { c) Periode } \\
\text { dicakup. } \\
\text { d) Mata yang } \\
\text { pelaporan. uang } \\
\text { e) Satuan angka yang } \\
\text { digunakan. }\end{array}$ & $\sqrt{ }$ & \\
\hline 3 & $\begin{array}{l}\text { Periode } \\
\text { pelaporan }\end{array}$ & $\begin{array}{l}\text { PSAP } 02 \text { paragraf } 11 \text { : } \\
\text { Penyajian laporan realisasi } \\
\text { anggaran } \\
\text { kurangnya disajikan sekurang- } \\
\text { dalam setahun. }\end{array}$ & $\begin{array}{l}\text { Penyajian laporan realisasi } \\
\text { anggaran realisasi anggaran } \\
\text { sekurang-kurangnya } \\
\text { disajikan sekali } \\
\text { setahun. }\end{array}$ & $\sqrt{ }$ & \\
\hline 4 & $\begin{array}{l}\text { Ketepatan waktu } \\
\text { penyajian }\end{array}$ & $\begin{array}{l}\text { PSAP } 02 \text { paragraf 12: Entitas } \\
\text { menyajikan laporan realisasi } \\
\text { anggaran selambat-lambatnya } \\
6 \text { bulan setelah berakhirnya } \\
\text { tahun anggaran. }\end{array}$ & $\begin{array}{l}\text { Inspektorat Kabupaten } \\
\text { Enrekang menyajikan laporan } \\
\text { realisasi anggaran selambat- } \\
\text { lambatnya } 6 \text { bulan setelah } \\
\text { berakhirnya tahun anggaran. }\end{array}$ & $\sqrt{ }$ & \\
\hline 5 & $\begin{array}{l}\text { Penyajian } \\
\text { informasi realisasi } \\
\text { pendapatan-LRA, } \\
\text { belanja, transfer, } \\
\text { surplus/defisit- } \\
\text { LRA dan } \\
\text { pembiayaan. }\end{array}$ & 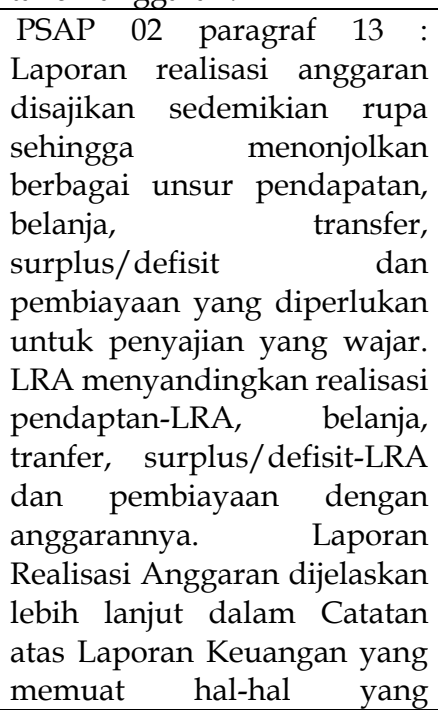 & $\begin{array}{lr}\text { Laporan realisasi anggaran } \\
\text { disajikan sedemikian rupa } \\
\text { sehingga menonjolkan } \\
\text { berbagai unsur pendapatan, } \\
\text { belanja, } \\
\text { surplus/defisitransfer, } \\
\text { pembiayaan yang diperlukan } \\
\text { untuk penyajian yang wajar. } \\
\text { LRA menyandingkan realisasi } \\
\text { pendaptan-LRA, belanja, } \\
\text { tranfer, surplus/defisit-LRA } \\
\text { dan pembiayaan dengan } \\
\text { anggarannya. } \\
\text { Realisasi Anggaran dijelaskan } \\
\text { lebih lanjut dalam Catatan } \\
\text { atas Laporan Keuangan yang } \\
\text { memuat hal-hal yang } \\
\text { mempengaruhi pelaksanaan }\end{array}$ & $\sqrt{ }$ & \\
\hline
\end{tabular}




\begin{tabular}{|c|c|c|c|c|}
\hline & & $\begin{array}{l}\text { mempengaruhi pelaksanaan } \\
\text { anggaran seperti kebijakan } \\
\text { fiskal dan moneter, sebab- } \\
\text { sebab terjadinya perbedaan } \\
\text { yang material antara } \\
\text { anggaran dan realisasinya, } \\
\text { serta daftar-daftar yang } \\
\text { merinci lebih lanjut angka- } \\
\text { anka yang dianggap perlu } \\
\text { untuk dijelaskan. }\end{array}$ & $\begin{array}{l}\text { anggaran seperti kebijakan } \\
\text { fiskal dan moneter, sebab- } \\
\text { sebab terjadinya perbedaan } \\
\text { yang material antara anggaran } \\
\text { dan realisasinya, serta daftar- } \\
\text { daftar yang merinci lebih } \\
\text { lanjut angka-anka yang } \\
\text { dianggap perlu untuk } \\
\text { dijelaskan. }\end{array}$ & \\
\hline 6 & $\begin{array}{l}\text { Penyajian pos-pos } \\
\text { dalam laporan } \\
\text { realisasi } \\
\text { anggaran. }\end{array}$ & $\begin{array}{l}\text { PSAP } 02 \text { paragraf } 14 \text { : Pos-pos } \\
\text { yang harus disajikan dalam } \\
\text { laporan realisasi anggaran } \\
\text { meliputi Pendapatan-LRA, } \\
\text { belanja, transfer, } \\
\text { surplus/defisit-LRA, } \\
\text { penerimaan pembiayaan, } \\
\text { pengeluaran pembiayaan, } \\
\text { pembiayaan neto dan sisa } \\
\text { lebih/kurang pembiayaan } \\
\text { anggaran (SiLPA/SiKPA). }\end{array}$ & $\begin{array}{l}\text { Pos-pos yang harus disajikan } \\
\text { dalam laporan realisasi } \\
\text { anggaran } \\
\text { Pendapatan-LRA, belanja, } \\
\text { transfer, surplus/defisit-LRA, } \\
\text { penerimaan pembiayaan, } \\
\text { pengeluaran pembiayaan, } \\
\text { pembiayaan neto dan sisa } \\
\text { lebih/kurang pembiayaan } \\
\text { anggaran (SiLPA/SiKPA). }\end{array}$ & $\sqrt{ }$ \\
\hline 7 & $\begin{array}{l}\text { Penyajian } \\
\text { Klasifikasi } \\
\text { pendapatan. }\end{array}$ & $\begin{array}{l}\text { PSAP } 02 \text { paragraf 17: Entitas } \\
\text { pelaporan menyajikan } \\
\text { klasifikasi pendapatan } \\
\text { menurut jenis pendapatan- } \\
\text { LRA dalam Laporan Realisasi } \\
\text { Anggaran dan rincian lebih } \\
\text { lanjut jenis pendapatan } \\
\text { disajikan pada Catatan atas } \\
\text { Laporan Keuangan. }\end{array}$ & $\begin{array}{l}\text { Inspektorat } \\
\text { Enrekang } \\
\text { klasifikasi menyajikan } \\
\text { menurut jenis } \\
\text { LRA dalam Lapondapatan Realisasi } \\
\text { Anggaran dan rincian lebih } \\
\text { lanjut jenis pendapatan } \\
\text { disajikan pada Catatan atas } \\
\text { Laporan Keuangan. }\end{array}$ & $\sqrt{ }$ \\
\hline 8 & $\begin{array}{l}\text { Penyajian } \\
\text { klasifikasi belanja. }\end{array}$ & $\begin{array}{l}\text { PSAP } 02 \text { paragraf 18: Entitas } \\
\text { pelaporan menyajikan } \\
\text { klasifikasi belanja dalam } \\
\text { Laporan Realisasi Anggaran. } \\
\text { Klasifikasi belanja menurut } \\
\text { organisasi disajikan dalam } \\
\text { Laporan Realisasi Anggaran } \\
\text { atau di Catatan atas Laporan } \\
\text { Keuangan. Klasifikasi belanja } \\
\text { menurut fungsi disajikan } \\
\text { dalam Catatan atas Laporan } \\
\text { Keuangan. }\end{array}$ & 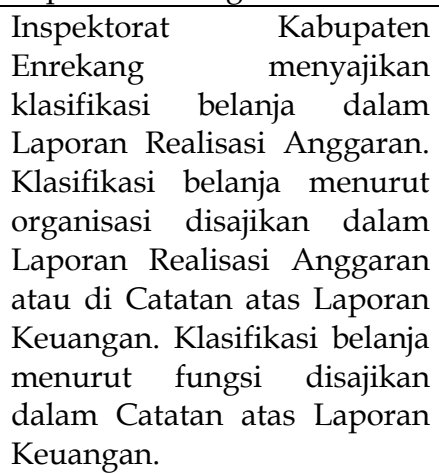 & $\sqrt{ }$ \\
\hline 9 & $\begin{array}{l}\text { Penyelenggaraan } \\
\text { akuntansi } \\
\text { anggaran }\end{array}$ & $\begin{array}{l}\text { PSAP } 02 \text { paragraf 20-21: } \\
\text { Akuntansi anggaran } \\
\text { diselenggaran sesuai dengan } \\
\text { struktur anggaran yang terdiri } \\
\text { dari anggaran pendapatan, } \\
\text { belanja dan pembiayaan pada } \\
\text { saat anggaran disahkan dan } \\
\text { dialokasikan. }\end{array}$ & $\begin{array}{l}\text { Akuntansi anggaran } \\
\text { diselenggaran sesuai dengan } \\
\text { struktur anggaran yang terdiri } \\
\text { dari anggaran pendapatan, } \\
\text { belanja dan pembiayaan pada } \\
\text { saat anggaran disahkan dan } \\
\text { dialokasikan. }\end{array}$ & $\sqrt{ }$ \\
\hline 10 & $\begin{array}{l}\text { Pengakuan } \\
\text { pendapatan-LRA }\end{array}$ & $\begin{array}{l}\text { PSAP } 02 \text { paragraf } \\
\text { Pendapatan } \\
\text { PLRA diakui } \\
\text { pada saat diterima pada } \\
\text { Rekening Kas Umum Negara } \\
\text { Daerah dan diklasifikasikan } \\
\text { menurut jenis pendapatan. }\end{array}$ & $\begin{array}{lr}\begin{array}{l}\text { Pengakuan pada } \\
\text { Realisasi }\end{array} & \begin{array}{l}\text { Laporan } \\
\text { anggaran }\end{array} \\
\text { Inspektorat } & \text { Kabupaten } \\
\text { Enrekang yaitu Pendapatan - } \\
\text { LRA diakui pada saat diterima } \\
\text { pada Rekening Kas Umum } \\
\text { Negara Daerah dan } \\
\text { diklasifikasikan menurut jenis } \\
\text { pendapatan. }\end{array}$ & $\sqrt{ }$ \\
\hline 11 & $\begin{array}{l}\text { Penyajian transfer } \\
\text { masuk }\end{array}$ & $\begin{array}{l}\text { PSAP } 02 \text { paragraf } 24 \text { : Transfer } \\
\text { masuk adalah penerimaan }\end{array}$ & $\begin{array}{l}\text { Inspektorat Kabupaten } \\
\text { Enrekang mengelompokkan }\end{array}$ & $\sqrt{ }$ \\
\hline
\end{tabular}




\begin{tabular}{|c|c|c|c|c|}
\hline & & $\begin{array}{l}\text { uang dari entitas pelaporan } \\
\text { lain, misalnya penerimaan } \\
\text { dana perimbangan dari } \\
\text { pemerintah pusat dan dana } \\
\text { bagi hasil dari pemerintah } \\
\text { provinsi. }\end{array}$ & $\begin{array}{l}\text { pendapatan transfer meliputi } \\
\text { pemerintah pusat-dana } \\
\text { perimbangan, transfer } \\
\text { pemerintah pusat lainnya dan } \\
\text { transfer pemerintah provinsi. }\end{array}$ & \\
\hline 12 & $\begin{array}{l}\text { Pelaksanaan } \\
\text { akuntansi } \\
\text { anggaran }\end{array}$ & $\begin{array}{l}\text { PSAP } 02 \text { paragraf 25: } \\
\text { Akuntansi pendapatan-LRA } \\
\text { dilaksanakan berdasarkan } \\
\text { azas bruto, yaitu dengan } \\
\text { membukukan penerimaan } \\
\text { bruto, dan tidak mencatat } \\
\text { jumlah netonya (setelah } \\
\text { dikompensasikan dengan } \\
\text { pengeluaran). }\end{array}$ & $\begin{array}{lr}\text { Akuntansi } & \text { pendapatan } \\
\text { Inspektorat } & \text { Kabupaten } \\
\text { Enrekang dilaksanakan } & \text { berdasarkan azas bruto, yaitu } \\
\text { dengan membukukan } & \text { menerimaan bruto, dan tidak } \\
\text { mencatat jumlah netonya } \\
\text { (setelah dikompensasikan } \\
\text { dengan pengeluaran). }\end{array}$ & $\sqrt{ }$ \\
\hline 13 & $\begin{array}{l}\text { Penyajian koreksi } \\
\text { pendapatan }\end{array}$ & 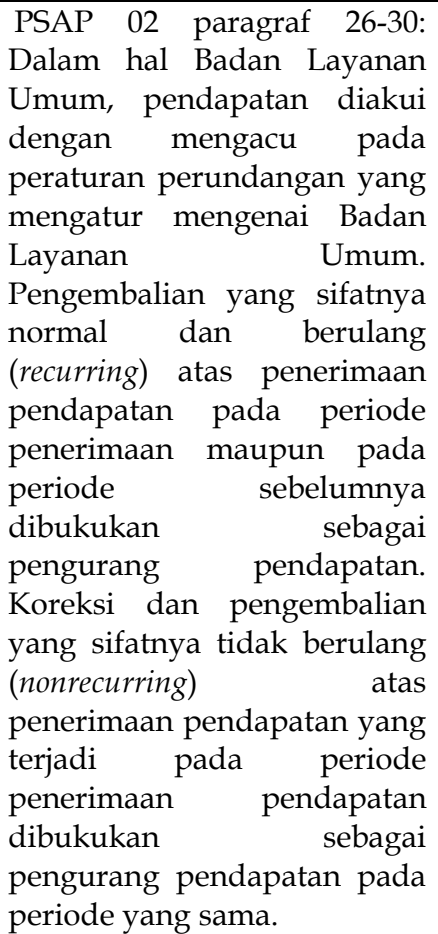 & 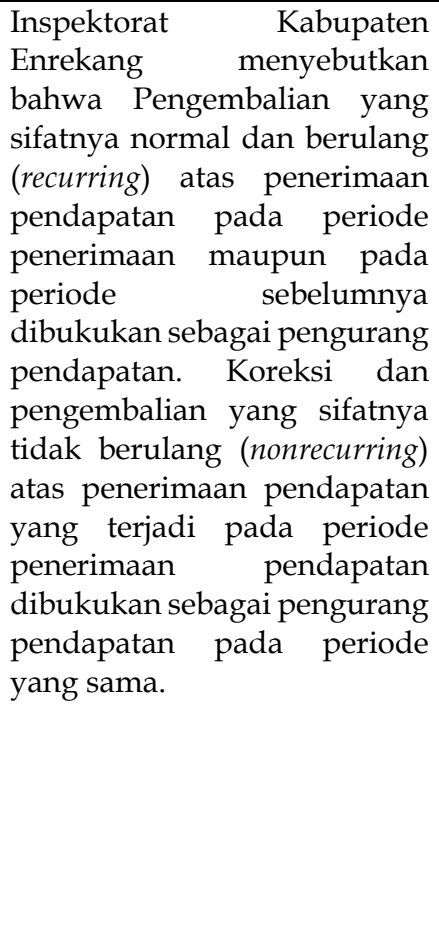 & $\sqrt{ }$ \\
\hline 14 & $\begin{array}{l}\text { Pengakuan } \\
\text { belanja }\end{array}$ & $\begin{array}{l}\text { PSAP } 02 \text { paragraf } 31-32 \text { : } \\
\text { Belanja diakui pada saat } \\
\text { terjadinya pengeluaran dari } \\
\text { Rekening Kas Umum } \\
\text { Negara/daerah, khsusnya } \\
\text { pengeluaran } \\
\text { bendahara melalui } \\
\text { pengakuannya terjadi pada } \\
\text { saat pertanggung jawaban } \\
\text { atas pengeluaran tersebut } \\
\text { disahkan oleh unit yang } \\
\text { mempunyai } \\
\text { perbendaharaan. }\end{array}$ & 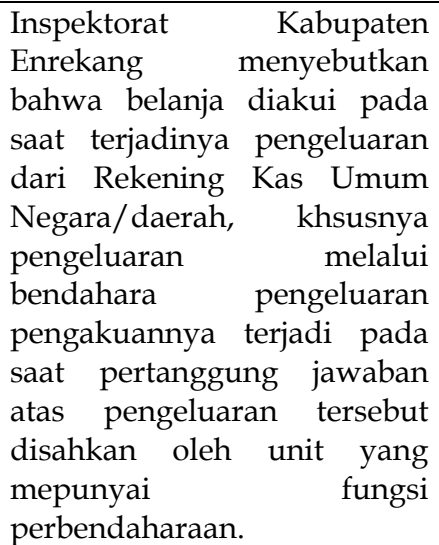 & $\sqrt{ }$ \\
\hline 15 & $\begin{array}{l}\text { Penyajian belanja } \\
\text { operasi }\end{array}$ & $\begin{array}{l}\text { PSAP } 02 \text { paragraf 36: Belanja } \\
\text { operasi adalah pengeluaran } \\
\text { anggaran untuk kegiatan } \\
\text { sehari-hari pemerintah } \\
\text { pusat/daerah yang memberi } \\
\text { manfaat jangka pendek. }\end{array}$ & $\begin{array}{lr}\text { Belanja } & \text { operasi } \\
\text { diklasifikasikan } & \text { menjadi } \\
\text { belanja pegawai, belanja } \\
\text { barang dan jasa, belanja hibah } \\
\text { dan belanja bantuan sosial. } \\
\text { Sifat dari belanja operasi di } \\
\text { Inspektorat } \quad \text { Kabupaten }\end{array}$ & $\sqrt{ }$ \\
\hline
\end{tabular}




\begin{tabular}{|c|c|c|c|c|}
\hline & & & $\begin{array}{l}\text { Enrekang sifatnya memberi } \\
\text { manfaat jangka pendek. }\end{array}$ & \\
\hline 16 & $\begin{array}{l}\text { Penyajian belanja } \\
\text { modal }\end{array}$ & $\begin{array}{l}\text { PSAP } 02 \text { paragraf } 37 \text { : Belanja } \\
\text { modal adalah pengeluaran } \\
\text { anggaran untuk perolehan } \\
\text { aset tetap dan aset lainnya } \\
\text { yang memberi manfaat lebih } \\
\text { dari satu periode akuntansi. } \\
\text { Belanja modal meliputi antara } \\
\text { lain belanja modal untuk } \\
\text { perolehan tanah,gedung dan } \\
\text { bangunan, peralatan, aset tak } \\
\text { berwujud. }\end{array}$ & $\begin{array}{l}\text { Pengklasifikasian belanja } \\
\text { modal Inspektorat Kabupaten } \\
\text { Enrekang } \\
\text { Dalam hal ini sesuai denagn } \\
\text { PSAP 02 paragraf } 37 \text { yaitu: } \\
\text { a) Belanja modal tanah. } \\
\text { b) Belanja modal } \\
\text { gedung dan } \\
\text { bangunan. } \\
\text { c) Belanja modal jalan, } \\
\text { irigasi dan jaringan. } \\
\text { d) Belanja modal aset } \\
\text { tetap lainnya. }\end{array}$ & $\sqrt{ }$ \\
\hline 17 & $\begin{array}{l}\text { Penyajian belanja } \\
\text { tak terduga }\end{array}$ & $\begin{array}{l}\text { PSAP } 02 \text { paragraf 38: Belanja } \\
\text { lain-lain tak terduga adalah } \\
\text { pengeluaran anggaran untuk } \\
\text { kegiatan yang sifatnya tidak } \\
\text { biasa dan tidak diharapkan } \\
\text { berulang seperti } \\
\text { penanggulangan bencana } \\
\text { alam, bencana sosial dan } \\
\text { pengeluaran tidak terduga } \\
\text { lainnya yang sangat } \\
\text { diperlukan dalam rangka } \\
\text { penyelenggaraan } \\
\text { kewenangan pemerintah } \\
\text { pusat/daerah. }\end{array}$ & $\begin{array}{l}\text { Dalam Inspektorat Kabupaten } \\
\text { Enrekang terdapat belanja tak } \\
\text { terduga dalam laporan } \\
\text { realisasi anggaran seperti } \\
\text { yang disebutkan dalam PSAP } \\
02 \text { paragraf } 38 \text {. }\end{array}$ & $\sqrt{ }$ \\
\hline 18 & $\begin{array}{l}\text { Penyajian transfer } \\
\text { keluar }\end{array}$ & $\begin{array}{l}\text { PSAP } 02 \text { paragraf 40: Transfer } \\
\text { keluar adalah pengeluaran } \\
\text { uang dari entitas pelaporan ke } \\
\text { entitas pelaporan lain seperti } \\
\text { pengeluaran dana } \\
\text { perimbangan oleh pemerintah } \\
\text { pusat dan dana bagi hasi oleh } \\
\text { pemerintah daerah. }\end{array}$ & $\begin{array}{l}\text { Transfer keluar yang disajikan } \\
\text { Inspektorat Kabupaten } \\
\text { Enrekang adalah transfer bagi } \\
\text { hasil pajak daerah dan bagi } \\
\text { hasil pendapatan lainnya serta } \\
\text { transfer bantuan keuangan } \\
\text { yang meliputi transfer } \\
\text { bantuan keuangan lainnya. }\end{array}$ & $\sqrt{ }$ \\
\hline 19 & $\begin{array}{l}\text { Penyajian koreksi } \\
\text { belanja }\end{array}$ & 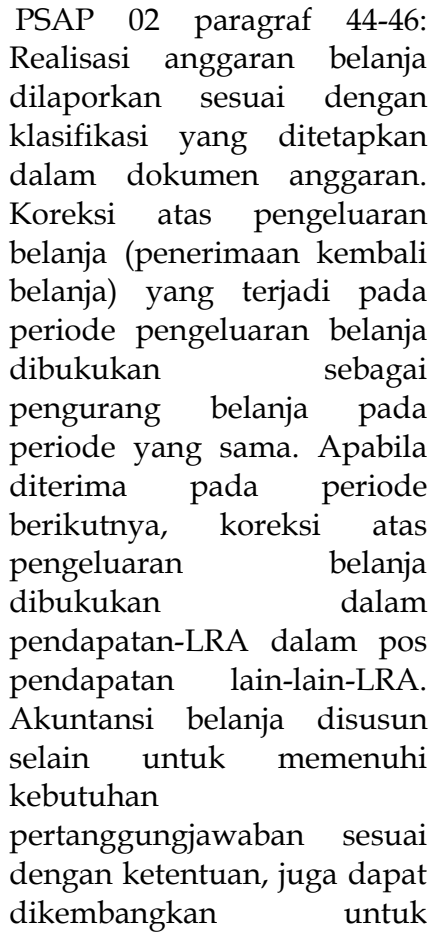 & $\begin{array}{l}\text { Inspektorat Kabupaten } \\
\text { Enrekang menjelaskan bahwa } \\
\text { Realisasi anggaran belanja } \\
\text { dilaporkan sesuai dengan } \\
\text { klasifikasi yang ditetapkan } \\
\text { dalam dokumen anggaran. } \\
\text { Koreksi atas pengeluaran } \\
\text { belanja (penerimaan kembali } \\
\text { belanja) yang terjadi pada } \\
\text { periode pengeluaran belanja } \\
\text { dibukukan sebagai pengurang } \\
\text { belanja pada periode yang } \\
\text { sama. Apabila diterima pada } \\
\text { periode berikutnya, koreksi } \\
\text { atas pengeluaran belanja } \\
\text { dibukukan dalam } \\
\text { pendapatan-LRA dalam pos } \\
\text { pendapatan lain-lain-LRA. } \\
\text { Akuntansi belanja disusun } \\
\text { selain untuk memenuhi } \\
\text { kebutuhan pesuai } \\
\text { pertanggungjawaban sesuan } \\
\text { dengan ketentuan, juga dapat } \\
\text { dikembangkan }\end{array}$ & $\sqrt{ }$ \\
\hline
\end{tabular}




\begin{tabular}{|c|c|c|c|c|}
\hline & & $\begin{array}{l}\text { keperluan pengendalian bagi } \\
\text { manajemen untuk mengukur } \\
\text { efektivitas dan efisiensi } \\
\text { belanja tersebut. }\end{array}$ & $\begin{array}{l}\text { keperluan pengendalian bagi } \\
\text { manajemen untuk mengukur } \\
\text { efektivitas dan efisiensi } \\
\text { belanja tersebut. }\end{array}$ & \\
\hline 20 & $\begin{array}{l}\text { Penyajian } \\
\text { Surplus/defisit- } \\
\text { LRA }\end{array}$ & $\begin{array}{l}\text { PSAP } 02 \text { paragraf } \\
\text { Surplus-LRA adalah selisih } \\
\text { lebih antara pendapatan-LRA } \\
\text { dan } 35 \text { belanja selama satu } \\
\text { periode pelaporan. Dan } \\
\text { defisit-LRA adalah selisih } \\
\text { kurang antara pendapatan- } \\
\text { LRA dan belanja selama satu } \\
\text { periode pelaporan. }\end{array}$ & $\begin{array}{l}\text { Selisih lebih/kurang antara } \\
\text { pendaatan dan belanja } \\
\text { tersebut dicatat dalam pos } \\
\text { surplus/defisit. }\end{array}$ & $\sqrt{ }$ \\
\hline 21 & $\begin{array}{l}\text { Penyajian } \\
\text { klasifikasi } \\
\text { pembiayaan }\end{array}$ & $\begin{array}{lr}\text { PSAP } 02 & \text { paragraf } 50: \\
\text { Pembiayaan } & \text { adalah seluruh } \\
\text { transaksi } & \text { keuangan } \\
\text { pemerintah. } & \text { Pembiayaan } \\
\text { dikelompokkan } & \text { menjadi } 2 \\
\text { yaitu } & \text { penerimaan } \\
\text { pembiayaan dan pengeluaran } \\
\text { pembiayaan. }\end{array}$ & $\begin{array}{lr}\text { Pembiayaan } & \text { Inspektorat } \\
\text { Kabupaten } & \text { Enrekang } \\
\text { dikelompokkan menjadi } 2 \\
\text { yaitu penerimaan pembiayaan } \\
\text { dan pengeluaran pembiayaan. }\end{array}$ & $\sqrt{ }$ \\
\hline 22 & $\begin{array}{l}\text { Penyajian } \\
\text { penerimaan } \\
\text { pembiayaan }\end{array}$ & $\begin{array}{lr}\text { PSAP } 02 & \text { paragraf 51: } \\
\text { Penerimaan } & \text { pembiayaan } \\
\text { adalah semua penerimaan } \\
\text { Rekening Kas Umum } \\
\text { Negara/Daerah antara lain } \\
\text { berasal dari penerimaan } \\
\text { pinjaman, penjualan obligasi } \\
\text { pemerintah, hasil privatisasi } \\
\text { perusahaan negara/daerah, } \\
\text { penerimaan } \\
\text { pinjaman yang diberikan } \\
\text { kepada fihak ketiga, } \\
\text { penjualan investasi permanen } \\
\text { lainnya dan pencaiaran dana } \\
\text { cadangan. }\end{array}$ & $\begin{array}{l}\text { Penerimaan pembiayaan } \\
\text { Inspektorat Kabupaten } \\
\text { Enrekang terdiri dari } \\
\text { penggunaan } \\
\text { penerimaan kembali piutang, } \\
\text { penerimaan kembali investasi } \\
\text { non permanen lainnya, dan } \\
\text { penerimaan kembali investasi } \\
\text { permanen. }\end{array}$ & $\sqrt{ }$ \\
\hline 23 & $\begin{array}{l}\text { Pengakuan } \\
\text { penerimaan } \\
\text { pembiayaan }\end{array}$ & $\begin{array}{l}\text { PSAP } 02 \text { paragraf 52: } \\
\text { Penerimaan pembiayaan } \\
\text { diakui pada saat diterima } \\
\text { pada Rekening Kas Umum } \\
\text { Negara/Daerah. }\end{array}$ & $\begin{array}{l}\text { Dalam kebijakan akuntansi } \\
\text { Inspektorat Kabupaten } \\
\text { Enrekang menjelaskan bahwa } \\
\text { penerimaan pembiayaan } \\
\text { diakui pada saat diterima } \\
\text { pada Rekening Kas Umum } \\
\text { Negara/Daerah. }\end{array}$ & $\sqrt{ }$ \\
\hline 24 & $\begin{array}{l}\text { Akuntansi } \\
\text { penerimaan } \\
\text { pembiayaan }\end{array}$ & $\begin{array}{lr}\text { PSAP } 02 & \text { paragraf 53: } \\
\text { Akuntansi } & \text { penerimaan } \\
\text { pembiayaan } & \text { dilaksanakan } \\
\text { berdasarkan azas bruto, yaitu } \\
\text { dengan } \\
\text { penerimaan bruto, dan tidak } \\
\text { mencatat jumlah netonya } \\
\text { (setelah dikompensasikan } \\
\text { dengan pengeluaran). }\end{array}$ & $\begin{array}{l}\text { Dalam kebijakan akuntansi } \\
\text { Inspektorat Kabupaten } \\
\text { Enrekang menjelaskan bahwa } \\
\text { Akuntansi penerimaan } \\
\text { pembiayaan dilaksanakan } \\
\text { berdasarkan azas bruto, yaitu } \\
\text { dengan membukukan } \\
\text { penerimaan bruto, dan tidak } \\
\text { mencatat jumlah netonya } \\
\text { (setelah dikompensasikan } \\
\text { dengan pengeluaran). }\end{array}$ & $\sqrt{ }$ \\
\hline 25 & $\begin{array}{l}\text { Penyajian } \\
\text { pengeluaran } \\
\text { pembiayaan }\end{array}$ & $\begin{array}{l}\text { PSAP } 02 \text { paragraf } 55: \\
\text { Pengeluaran pembiayaan } \\
\text { adalah semua pengeluaran } \\
\text { Rekening Kas Umum } \\
\text { Negara/Daerah antara lain } \\
\text { pemberian pinjaman kepada } \\
\text { pihak ketiga, penyertaan }\end{array}$ & 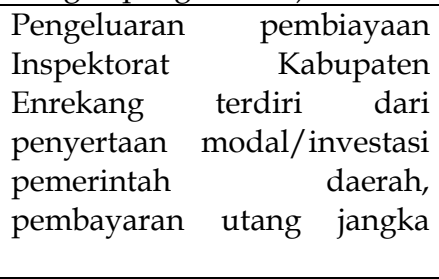 & $\sqrt{ }$ \\
\hline
\end{tabular}




\begin{tabular}{|c|c|c|c|c|}
\hline & & $\begin{array}{l}\text { modal pemerintah, } \\
\text { pembayaran kembali pokok } \\
\text { pinjaman dalam periode } \\
\text { tahun anggaran tertentu dan } \\
\text { pembentukan dana cadangan. }\end{array}$ & $\begin{array}{l}\text { panjang lainnya dan } \\
\text { pembayaran utang belanja. }\end{array}$ & \\
\hline 26 & $\begin{array}{l}\text { Pengakuan } \\
\text { pengeluaran } \\
\text { pembiayaan }\end{array}$ & $\begin{array}{l}\text { PSAP } 02 \text { paragraf 56: } \\
\text { Pengeluaran pembiayaan } \\
\text { diakui pada saat dikeluarkan } \\
\text { dari Rekening Kas Umum } \\
\text { Negara/Daerah. }\end{array}$ & 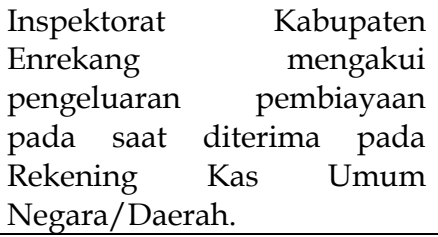 & $\sqrt{ }$ \\
\hline 27 & $\begin{array}{l}\text { Pengakuan } \\
\text { pembiayaan netto }\end{array}$ & $\begin{array}{l}\text { PSAP } 02 \text { paragraf 58-59: } \\
\text { pengeluaran } \\
\text { pada saat diterima pada } \\
\text { Rekening } \\
\text { Nas Umum } \\
\text { Negara/Daerah. }\end{array}$ & 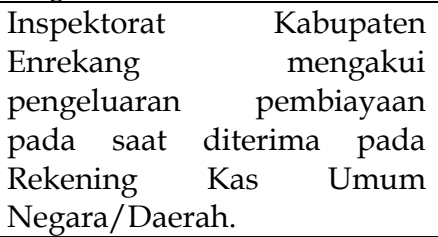 & $\sqrt{ }$ \\
\hline 28 & $\begin{array}{l}\text { Penyajian sisa } \\
\text { lebih/kurang } \\
\text { pembiayaan } \\
\text { anggaran. }\end{array}$ & $\begin{array}{lr}\text { PSAP } 02 \text { paragraf } & 60-61: \\
\text { SiLPA/SiKPA adalah selisih } \\
\text { lebih/kurang antara realisasi } \\
\text { penerimaan dan pengeluaran } \\
\text { selama satu periode } \\
\text { pelaporan. } & \text { Selisih } \\
\text { lebih/kurang antara realisasi } \\
\text { pendapatan-LRA dan belanja } \\
\text { serta penerimaan dan } \\
\text { pengeluaran pembiayaan } \\
\text { selama satu periode } \\
\text { pelaporan dicatat dalam pos } \\
\text { SiLPA/SiKPA. }\end{array}$ & \begin{tabular}{lr} 
Inspektorat & \multicolumn{2}{c}{ Kabupaten } \\
Enrekang mencatat selisih \\
penerimaan dan pengeluaran \\
pembiayaan selama satu \\
periode pelaporan yang \\
dicatat dalam & pso \\
SiLPA/SiKPA. &
\end{tabular} & $\sqrt{ }$ \\
\hline 29 & $\begin{array}{l}\text { Penyajian } \\
\text { transaksi dalam } \\
\text { mata uang asing }\end{array}$ & $\begin{array}{l}\text { PSAP } 02 \text { paragraf 62: } \\
\text { Transaksi mata uang asing } \\
\text { harus dibukukan dalam mata } \\
\text { uang rupiah. }\end{array}$ & 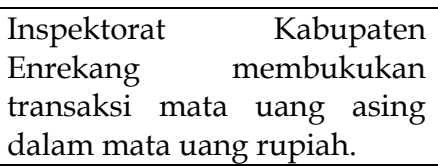 & $\sqrt{ }$ \\
\hline 30 & $\begin{array}{l}\text { Penyajian } \\
\text { transaksi } \\
\text { pendapatan, } \\
\text { belanja dan } \\
\text { pembiayaan } \\
\text { dalam bentuk } \\
\text { barang dan jasa. }\end{array}$ & $\begin{array}{l}\text { PSAP } 02 \text { paragraf 63: } \\
\text { Transaksi pendapatan, belanja } \\
\text { dan pembiayaan dalam } \\
\text { bentuk barang dan jasa, harus } \\
\text { dilaporkan dalam laporan } \\
\text { realisasi anggarannya dengan } \\
\text { cara menaksir nilai barang } \\
\text { dan jasa tersebut pada tanggal } \\
\text { transaksi. }\end{array}$ & $\begin{array}{l}\text { Inspektorat } \\
\text { Enrekang menerapkan jika } \\
\text { setiap ada transaksi } \\
\text { pendapatan, belanja dan } \\
\text { pembiayaan dalam bentuk } \\
\text { barang dan jasa, maka } \\
\text { pelaporan dalam laporan } \\
\text { realisasi anggarannya dengan } \\
\text { cara menaksir nilai barang } \\
\text { dan jasa tersebut pada tanggal } \\
\text { transaksi. }\end{array}$ & $\sqrt{ }$ \\
\hline
\end{tabular}

Dari tabel ringkasan di atas dapat diketahui bahwa Inspektorat Kabupaten Enrekang dalam menyajikan laporan realisasi anggarannya telah menerapkan PP Nomor 71 tahun 2010. Hasil penelitian ini menemukan bahwa Inspektorat Kabupaten Enrekang dalam menyajikan laporan realisasi anggaran telah mengacu pada PSAP 02 tentang laporan realisasi anggaran yang terdiri dari 43 paragraf yaitu : paragraf 9 , paragraf 10 , paragraf 11 , paragraf 12 , paragraf 13 , paragraf 14 , paragraf 17 , paragraf 18 , paragraf 20-21, paragraf 22-23, paragraf 24, pargraf 25, paragraf 26-30, paragraf 31-32, paragraf 36, paragraf 37, paragraf 38 , paragraf 40 , paragraf $44-46$, paragraf $47-49$, paragraf 50 , paragraf 51 , paragraf 52 , paragraf 53, paragraf 55, paragraf 56, paragraf 60-61, paragraf 62 dan paragraf 63.

Hasil analisis juga menemukan bahwa realisasi anggaran tahun 2019 disusun berdasarkan jumlah realisasi belanja dan pembiayaan yang dibandingkan dengan masing-masing anggarannya sesuai dengan DPA Inspektorat Kab. Enrekang tahun 2019. Jumlah angka yang tercantum dalam laporan realisasi anggaran ini mencakup semua penerimaan pendapatan dan pengeluaran belanja serta pembiayaan yang masuk ke dalam atau dikeluarkan dari bendahara Inspektorat Kabupaten Enrekang. 
Belanja diakui pada saat terjadinya pengeluaran dari rekening kas daerah, belanja sudah diklasifikasikan menurut klasifikasi ekonomi (jenis belanja). Penerimaan pembiayaan diakui pada saat diterima pada rekening kas dan juga pengeluaran pembiayaan diakui pada saat dikeluarkan dari rekening kas. Selisih lebih/kurang antara realisasi penerimaan dan pengeluaran selama satu periode pelaporan dicatat dalam pos SilPA/SikPA. Dalam penyajian laporan keuangan Inspektorat Kabupaten Enrekang juga telah menggambarkan perbandingan antara anggaran dengan realisasinya dalam satu periode pelaporan dan menyajikan sekurang-kurangnya unsur-unsur seperti (a) pendapatan-LRA, (b) belanja, (c) transfer, (d) surplus/defisit-LRA, (e) pembiayaan, (f) sisa lebih/kurang pembiayaan anggaran.

Dari uraian di atas dapat disimpulkan bahwa dalam penyusunan Laporan Realisasi Anggaran Inspektorat Kabupaten Enrekang telah sesuai dengan penerapan PP No. 71 Tahun 2010 tentang Standar Akuntansi Pemerintahan berbasis akrual. Hasil penelitian ini mendukung hasil penelitian Ningtyas (2015) yang menyatakan bahwa penyajian Laporan Realisasi Anggaran Dinas Energi dan Sumber Daya Mineral Provinsi Sulawesi Utara secara keseluruhan telah sesuai dengan PP Nomor 71 Tahun 2010 tentang Standar Akuntansi Pemerintah. Penyajian pendapatan telah diklasifikasikan menurut jenis pendapatan yang terdiri dari Pendapatan Asli Daerah dan Pendapatan Transfer. Penyajian belanja telah diklasifikasikan menurut jenis belanja yang terdiri dari Belanja Operasi, Belanja Modal, Belanja Tak Terduga, dan Transfer. Hasil penelitian ini juga sesuai dengan hasil penelitian Mentu dan Sondakh (2016) yang menyatakan bahwa pada Laporan Realisasi Anggaran Dinas Pendapatan Daerah tahun anggaran 2014 dan Dinas Sosial tahun anggaran 2015 secara keseluruhan telah sesuai dengan PP Nomor 71 Tahun 2010 tentang Standar Akuntansi Pemerintahan.

Namun hasil penelitian ini berbeda dengan hasil penelitian yang ditemukan oleh Penyajian Laporan Realisasi Anggaran pemerintah Kota Manado tahun 2011 belum sesuai PSAP No. 2 ayat 14 tahun 2005. Penyajian Laporan Realisasi Anggaran yang sesuai Standar Akuntansi Pemerintahan, dengan menunjukkan penyajian laporan keuangan pemerintah Kota Manado tahun 2011 pada pos pendapatan telah sesuai dengan PSAP No. 2 ayat 22, 23 dan 24 tahun 2005. Penyajian belanja operasi yang meliputi belanja pegawai, belanja barang, belanja hibah, dan belanja bantuan sosial telah sesuai dengan PSAP No. 2 ayat 36 tahun 2005, sedangkan belanja bagi hasil kepada provinsi/kab./kota dan pemerintah desa tidak termasuk dalam belanja operasi maka hal ini tidak sesuai dengan Standar Akuntansi Pemerintahan.

\subsection{Analisa Laporan Operasional (LO)}

Menyusun Laporan Operasional (LO) dapat langsung dihasilkan dengan mengambil data akunakun kode rekening 8 untuk pendapatan-LO dan kode rekening 9 untuk Beban. Laporan operasional Inspektorat Kab. Enrekang dapat disajikan dalam tabel berikut:

Tabel 5. Laporan Operasional Per 31 Desember 2019 Dan 2018

\begin{tabular}{|c|l|c|c|}
\hline NO & \multicolumn{1}{|c|}{ URAIAN } & TAHUN 2019 & TAHUN 2018 \\
\hline 1 & \multicolumn{1}{|c|}{ PENDAPATAN } & & \\
\hline 2 & \multicolumn{1}{|c|}{ PENDAPATAN ASLI DAERAH (PAD)-LO } & $\mathbf{0 , 0 0}$ & $\mathbf{0 , 0 0}$ \\
\hline 3 & Pendapatan Pajak Daerah-LO & 0,00 & 0,00 \\
\hline 4 & Pendapatan Retribusi Daerah - LO & 0,00 & 0,00 \\
\hline & $\begin{array}{l}\text { Pendapatan Hasil Pengelolaan Kekayaan Daerah Yang } \\
\text { Dipisahkan - LO }\end{array}$ & 0,00 & 0,00 \\
\hline 6 & Lain-Lain PAD yang Sah - LO & 0,00 & 0,00 \\
\hline & & & $\mathbf{0 , 0 0}$ \\
\hline 7 & PENDAPATAN TRANSFER - LO & $\mathbf{0 , 0 0}$ & 0,00 \\
\hline 8 & Transfer Pemerintah Pusat - Dana Perimbangan - LO & 0,00 & 0,00 \\
\hline 9 & Pendapatan Transfer Pemerintah Pusat - Lainnya - LO & 0,00 & 0,00 \\
\hline 10 & Pendapatan Transfer Pemerintah Daerah - Lainnya - LO & 0,00 & 0,00 \\
\hline 11 & Bantuan Keuangan - LO & 0,00 & \\
\hline & & & \\
\hline
\end{tabular}




\begin{tabular}{|c|c|c|c|}
\hline 12 & $\begin{array}{l}\text { LAIN-LAIN PENDAPATAN DAERAH YANG SAH - } \\
\text { LO }\end{array}$ & 0,00 & 0,00 \\
\hline 13 & Pendapatan Hibah - LO & 0,00 & 0,00 \\
\hline 14 & Dana Darurat - LO & 0,00 & 0,00 \\
\hline 15 & Pendapatan Lainnya - LO & 0,00 & 0,00 \\
\hline 16 & Jumlah Lain-lain Pendapatan Yang Sah & 0,00 & 0,00 \\
\hline 17 & JUMLAH PENDAPATAN & 0,00 & 0,00 \\
\hline 26 & BEBAN & $8.486 .129 .729,01$ & $8.774 .438 .045,90$ \\
\hline 27 & BEBAN OPERASI - LO & $8.486 .129 .729,01$ & $8.774 .438 .045,90$ \\
\hline 28 & Beban Pegawai - LO & 3.947.403.687,00 & 4.096.064.117,00 \\
\hline \multirow[t]{2}{*}{29} & Beban Barang dan Jasa & $4.072 .411 .703,00$ & $4,139,584,316,33$ \\
\hline & Beban Persediaan & $455.277 .500,00$ & $540.084 .248,00$ \\
\hline 30 & Beban Jasa & $342.491 .314,00$ & $142.594 .567,00$ \\
\hline 31 & Beban Perjalanan Dinas & $3.246 .021 .071,00$ & $3.429 .486 .413,00$ \\
\hline 32 & Beban Pemeliharaan & $28.621 .818,00$ & $27.419 .088,33$ \\
\hline 33 & Beban Bunga & 0,00 & 0,00 \\
\hline 34 & Beban Subsidi & 0,00 & 0,00 \\
\hline 35 & Beban Hibah & 0,00 & 0,00 \\
\hline 36 & Beban Bantuan Sosial & 0,00 & 0,00 \\
\hline \multirow[t]{2}{*}{37} & Beban Penyusutan dan Amortisasi & $191.204 .260,00$ & $224.978 .663,57$ \\
\hline & Beban Penyisihan Piutang & 0,00 & 0,00 \\
\hline 38 & Beban Lain-lain & $275.110 .079,00$ & $279.244 .451,00$ \\
\hline 40 & BEBAN TRANSFER & 0,00 & 0,00 \\
\hline 41 & Beban Transfer Bagi Hasil Pajak & 0,00 & 0,00 \\
\hline 42 & Beban Transfer Bagi Hasil Pendapatan Lainnya & 0,00 & 0,00 \\
\hline 43 & $\begin{array}{l}\text { Beban Transfer Bantuan Keuangan ke Pemerintah } \\
\text { Daerah Lainnya }\end{array}$ & 0,00 & 0,00 \\
\hline 44 & Beban Transfer Bantuan Keuangan ke Desa & 0,00 & 0,00 \\
\hline 45 & Beban Transfer Keuangan Lainnya & 0,00 & 0,00 \\
\hline 46 & Beban Transfer Dana Otonomi Khusus & 0,00 & 0,00 \\
\hline 47 & JUMLAH BEBAN & $8.486 .129 .729,01$ & $8.774 .438 .045,90$ \\
\hline 48 & JUMLAH SURPLUS / DEFISIT DARI OPERASI & $(8.486 .129 .729,01)$ & $(8.774 .438 .045,90)$ \\
\hline 49 & $\begin{array}{l}\text { SURPLUS / DEFISIT DARI KEGIATAN NON } \\
\text { OPERASIONAL }\end{array}$ & 0,00 & 0,00 \\
\hline 50 & SURPLUS NON OPERASIONAL - LO & 0,00 & 0,00 \\
\hline 51 & Surplus Penjualan Aset Non Lancar - LO & 0,00 & 0,00 \\
\hline 52 & $\begin{array}{l}\text { Surplus Penyelesaian Kewajiban Jangka } \\
\text { Panjang - LO }\end{array}$ & 0,00 & 0,00 \\
\hline 53 & $\begin{array}{l}\text { Surplus dari Kegiatan Non Operasional } \\
\text { Lainnya - LO }\end{array}$ & 0,00 & 0,00 \\
\hline 54 & Jumlah Surplus Non Operasional & 0,00 & 0,00 \\
\hline 55 & DEFISIT NON OPERASIONAL & 0,00 & 0,00 \\
\hline 56 & Defisit Penjualan Aset Non Lancar - LO & 0,00 & 0,00 \\
\hline 58 & Defisit Penyelesian Kewajiban Jangka Panjang - LO & 0,00 & 0,00 \\
\hline 59 & Defisit Dari Kegiatan Non Operasional Lainnya - LO & 0,00 & 0,00 \\
\hline 60 & Jumlah Defisit Non Operasional & 0,00 & 0,00 \\
\hline 61 & $\begin{array}{l}\text { JUMLAH SURPLUS/ DEFISIT DARI KEGIATAN } \\
\text { NON OPERASIONAL }\end{array}$ & 0,00 & 0,00 \\
\hline
\end{tabular}




\begin{tabular}{|c|l|c|c|}
\hline & & & \\
\hline 62 & SURPLUS / DEFISIT SEBELUM POS LUAR BIASA & $\mathbf{( 8 . 4 8 6 . 1 2 9 . 7 2 9 , 0 1 )}$ & $\mathbf{( 8 . 7 7 4 . 4 3 8 . 0 4 5 , 9 0 )}$ \\
\hline & & & $\mathbf{0}$ \\
\hline 63 & PENDAPATAN LUAR BIASA - LO & $\mathbf{0 , 0 0}$ & $\mathbf{0 , 0 0}$ \\
\hline 65 & Pendapatan Luar Biasa & 0,00 & 0,00 \\
\hline 66 & Jumlah Pendapatan Luar Biasa & $\mathbf{0 , 0 0}$ & $\mathbf{0 , 0 0}$ \\
\hline & & $\mathbf{0 , 0 0}$ & $\mathbf{0 , 0 0}$ \\
\hline 67 & BEBAN LUAR BIASA & 0,00 & 0,00 \\
\hline 68 & Beban Luar Biasa & $\mathbf{0 , 0 0}$ & $\mathbf{0 , 0 0}$ \\
\hline 69 & Jumlah Beban Luar Biasa & $\mathbf{0 , 0 0}$ & $\mathbf{0 , 0 0}$ \\
\hline 70 & JUMLAH BEBAN LUAR BIASA & & \\
\hline \multicolumn{2}{|l|}{} & $\mathbf{( 8 . 4 8 6 . 1 2 9 . 7 2 9 , 0 1 )}$ & $\mathbf{( 8 . 7 7 4 . 4 3 8 . 0 4 5 , 9 0 )}$ \\
\hline 71 & SURPLUS / DEFISIT - LO &
\end{tabular}

Sumber : Laporan Keuangan Inspektorat Kab. Enrekang 2019

Berdasarkan laporan LO Inspektorat Kabupaten Enrekang tahun 2019 di atas diperoleh nilai defisit sebesar Rp.8.486.129.729,01 yang diperoleh dari beban beban operasi yang terdiri dari beban pegawai Rp.3.947.403.687,00, beban barang dan jasa Rp4.072.411.703,00 beban penyusutan Rp.191.204.260,00 dan beban lain-lain sebesar Rp.275.110.079,00. Diketahui bahwa Inspektorat Kabupaten Enrekang dalam menyajikan laporan operasional (LO) telah menerapkan PP Nomor 71 tahun 2010. Laporan operasional (LO) menyajikan berbagai unsur pendapatan LO, beban, surplus/defisit dari kegiatan operasional, surplus/defisit dari kegiatan non operasional, surplus/defisit sebelum pos luar biasa, pos luar biasa dan surplus/defisit-LO, yang diperlukan untuk penyajian yang wajar secara komparatif. Hasil penelitian ini menemukan bahwa Inspektorat Kabupaten Enrekang dalam menyajikan laporan operasional telah menerapkan PP No.71 Tahun 2010 dan mengacu pada PSAP 12 tentang laporan operasional. Laporan operasional Inspektorat Kabupaten Enrekang telah menyajikan pos-pos sebagai berikut: (a) Pendapatan-LO dari kegiatan operasional, (b) Beban dari kegiatan operasional, (c) Surplus/defisit dari kegiatan operasional, (d) Kegiatan Non operasional, (e) Surplus/defisit sebelum Pos Luar Biasa, (f) Pos Luar Biasa, (g) Surplus/defisit-LO.

Maka dapat disimpulkan bahwa dalam penyusunan Laporan Operasional Inspektorat Kabupaten Enrekang telah sesuai dengan penerapan PP No. 71 Tahun 2010 tentang Standar Akuntansi Pemerintahan berbasis akrual. Hasil penelitian ini mendukung hasil penelitian Mantiri, Saerang dan Elim (2016) yang menyatakan bahwa mencakup kegiatan operasional dan kegiatan non operasional, pos-pos yang terdapat dalam kegiatan operasional antara lain Pendapatan Asli Daerah (PAD)-LO, Pendapatan Transfer-LO, Lain-lain pendapatan daerah yang sah-LO, untuk pos beban didalamnya terdapat beban pegawai-LO, beban barang dan jasa, beban bunga, beban subsidi dan lain sebagainya. Untuk kegiatan non operasional antara lain Surplus Penjualan Aset Non Lancar-LO, Surplus Penyelesaian Kewajiban Jangka Panjang-LO, Surplus dari kegiatan Non operasonal Lainnya-LO dan lain sebagainya.

\subsection{Analisa Laporan Perubahan Ekuitas}

Laporan Perubahan Ekuitas pada Inspektorat Kabupaten Enrekang menyajikan informasi kenaikan atau penurunan ekuitas tahun pelaporan dibandingkan dengan tahun sebelumnya. Selain itu, laporan ekuitas Inspektorat Kabupaten Enrekang juga menyajikan posisi keuangan tahun sebelumnya yakni tahun 2018 sebagai pembanding dengan tahun 2019. Berikut laporan perubahan ekuitas Inspektorat Kabupaten Enrekang periode 2018 dan 2019. Berdasarkan laporan perubahan ekuitas Inspektorat Kabupaten Enrekang tahun 2019 di atas diperoleh nilai Ekuitas Akhir sebesar Rp. 1.322.232.308,97 yang diperoleh dari penjumlahan Nilai Ekuitas Awal tahun 2018 sebesar Rp.1.402.250.310,98, ditambah dengan surplus/defisit-LO sebesar (Rp.8.486.129.729,01) yang diperoleh dari Laporan Operasional, ditambah (RK-PPKD) Ekuitas untuk dikonsolidasikan sebesar Rp.8.353.023.727,00 dan Koreksi Nilai Aset Tetap sebesar Rp. 53.088.000,00. Hasil penelitian ini menemukan bahwa Inspektorat Kabupaten Enrekang dalam menyajikan laporan perubahan ekuitas telah mengacu pada PSAP paragraf 101-102. Dalam Laporan Perubahan Ekuitas pada Inspektorat Kabupaten Enrekang menyajikan pos-pos: (a) Ekuitas awal, (b) Surplus/defisit-LO pada periode 
bersangkutan, (c) Koreksi-koreksi yang langsung menambah/mengurangi ekuitas, yang antara lain berasal dari dampak kumulatif yang disebabkan oleh perubahan Kebijakan Akuntansi dan koreksi kesalahan mendasar misalnya koreksi kesalahan mendasar dari persediaan yang terjadi pada periodeperiode sebelumnya, perubahan nilai aset tetap karena revaluasi aset tetap dan ekuitas akhir. Berdasarkan uraian di atas, maka dapat disimpulkan dalam laporan perubahan ekuitas Inspektorat Kabupaten Enrekang telah sesuai dengan penerapan PP No. 71 Tahun 2010 tentang Standar Akuntansi Pemerintahan berbasis akrual. Hasil penelitian ini mendukung hasil penelitian Mentu dan Sondakh (2016) yang menyatakan bahwa dalam hal pengklasifikasian ekuitas secara terpisah menjadi ekuitas dana lancar, ekuitas investasi dan ekuitas dana cadangan tidak sesuai dengan PSAP No. 1 ayat 84 dalam PP 71 Tahun 2010 yang merangkum semua kekayaan bersih pemerintah yang merupakan selisih antara aset dan kewajiban menjadi ekuitas.

Tabel 6. Laporan Perubahan Ekuitas Untuk Tahun Yang Berakhir Sampai Dengan 31 Desember 2019 Dan 2018

\begin{tabular}{|c|l|c|c|}
\hline NO & \multicolumn{1}{|c|}{ URAIAN } & 2019 & 2018 \\
\hline 1 & Ekuitas Awal & $1.402 .250 .310,98$ & $1.747 .873 .249,74$ \\
\hline 2 & Surplus/Defisit-Lo & $(8.486 .129 .729,01)$ & $(8.774 .438 .045,90)$ \\
\hline 3 & $\begin{array}{l}\text { Dampak Kumulatif Perubahan } \\
\text { Kebijakan/Kesalahan Mendasar: }\end{array}$ & \\
\hline 4 & (Rk-Ppkd) Ekuitas Untuk Dikonsolidasikan & $8.353 .023 .727,00$ & $8.514 .307 .042,00$ \\
\hline 5 & Koreksi Nilai Aset Tetap & $53.088 .000,00$ & $(17.913 .000,00)$ \\
\hline 6 & $\begin{array}{l}\text { Koreksi Nilai Persediaan } \\
\text { Penyesuaian Akumulasi Penyusutan }\end{array}$ & & $34.566 .498,00$ \\
7 & Aset Tetap & 0,00 & $(6.791 .930,86)$ \\
\hline 8 & $\begin{array}{l}\text { Penyesuaian Eliminasi Rk } \\
\text { Dinas Dan Rk Kasda }\end{array}$ & 0,00 & $34.566 .498,00$ \\
\hline 9 & $\begin{array}{l}\text { Perhit. Mutasi Masuk/Keluar \& } \\
\text { Koreksi Aset Tetap }\end{array}$ & 0,00 & $(129.920 .000,00$ \\
\hline 18 & Ekuitas Akhir & $1.322 .232 .308,97$ & $1.402 .250 .310,98$ \\
\hline
\end{tabular}

Sumber : Laporan Keuangan Inspektorat Kab. Enrekang T.A 2019

\subsection{Analisa Neraca}

Neraca merupakan laporan keuangan yang menggambarkan posisi keuangan mengenai aset, kewajiban dan ekuitas dana pada tanggal tertentu. Neraca Inspektorat Kabupaten Enrekang tahun 2019 menyajikan pos-pos aset yang terbagi menjadi aset lancar, investasi jangka panjang, aset tetap, dana cadangan dan aset lainnya. Kewajiban diklasifikasikan menjadi kewajiban jangka pendek dan kewajiban jangka panjang. Terakhir pos ekuitas dana terdiri dari ekuitas dana lancar, ekuitas dana investasi dan ekuitas dana cadangan. Selain itu, neraca Inspektorat Kabupaten Enrekang juga menyajikan posisi keuangan tahun sebelumnya yakni tahun 2018 sebagai pembanding dengan tahun 2019. Berikut Neraca Inspektorat Kabupaten Enrekang periode 2018 dan 2019. Berdasarkan Neraca Inspektorat Kab. Enrekang tahun 2019 di atas diperoleh nilai total aset sebesar Rp. 1.331.159.769,97 yang terdiri dari aset lancar Rp.3.607.419,50, aset tetap Rp.1.274.464.350,47 dan aset lain-lain sebesar Rp. 53.088.000,00 sedangkan nilai kewajiban dan ekuitas didapatkan sebesar Rp.1.331.159.769,97 yang terdiri dari utang jangka pendek sebesar Rp. 8.927.461,00, utang jangka panjang sebesar Rp. 0,00 dan nilai ekuitas sebesar Rp. 1.322.232.308,97 yang diperoleh dari Laporan Perubahan Ekuitas. Neraca daerah merupakan salah satu dari laporan keuangan daerah yang menyajikan informasi mengenai posisi aktiva, utang dan ekuitas dana pada akhir tahun anggaran. Hasil penelitian ini membuktikan bahwa Inspektorat Kabupaten Enrekang dalam menyusun neraca dengan cara mengumpulkan, menganalisis, mencatat anggaran dan realisasinya ke dalam pos-pos neraca. Inspektorat Kabupaten Enrekang telah menerapkan PP Nomor 71 Tahun 2010 dengan mengklasifikasikan asetnya dalam aset lancar dan non lancar serta mengkasifikasikan kewajibannya menjadi kewajiban jangka pendek dan jangka panjang dalam neraca. Sedangkan ekuitas adalah kekayaan bersih pemerintah yang merupakan selisih antara aset dan kewajiban pemerintah pada tanggal laporan. 
Tabel 7. Neraca Per 31 Desember 2019 Dan 2018

\begin{tabular}{|c|c|c|c|}
\hline No & Uraian & Tahun 2019 & Tahun 2018 \\
\hline & ASET & 1.331.159.769,97 & 1.408.487.797,98 \\
\hline 1 & ASET LANCAR & $3.607 .419,50$ & $2.862 .687,50$ \\
\hline 2 & Kas dan Setara Kas & 0,00 & 0,00 \\
\hline 3 & Investasi Jangka Pendek & 0,00 & 0,00 \\
\hline 4 & Piutang Pendapatan & 0,00 & 0,00 \\
\hline 5 & Piutang Lainnya & 0,00 & 0,00 \\
\hline 7 & Penyisihan Piutang & 0,00 & 0,00 \\
\hline 8 & Beban Dibayar Dimuka & $2.666 .919,50$ & $1.982 .687,50$ \\
\hline 9 & Persediaan & $940.500,00$ & $880.000,00$ \\
\hline 10 & Aset Untuk Dikonsolidasikan & 0,00 & 0,00 \\
\hline 11 & INVESTASI JANGKA PANJANG & 0,00 & 0,00 \\
\hline 12 & $\begin{array}{l}\text { Investasi Jangka Panjang Non } \\
\text { Permanen }\end{array}$ & 0,00 & 0,00 \\
\hline 13 & Investasi Jangka Panjang Permanen & 0,00 & 0,00 \\
\hline 34 & & & \\
\hline 35 & ASET TETAP & 1.274.464.350,47 & $1.405 .625 .110,48$ \\
\hline 36 & Tanah & $375.000 .000,00$ & $375.000 .000,00$ \\
\hline 37 & Peralatan dan Mesin & $1.752 .583 .473,00$ & $1.766 .522 .573,00$ \\
\hline 38 & Gedung dan Bangunan & $695.566 .750,00$ & $695.566 .750,00$ \\
\hline 39 & Jalan, Irigasi dan Jaringan & 0,00 & 0,00 \\
\hline 40 & Aset Tetap Lainnya & 0,00 & 0,00 \\
\hline 41 & Konstruksi Dalam Pengerjaan & 0,00 & 0,00 \\
\hline 42 & Akumulasi Penyusutan & $(1.548 .685 .872,53)$ & $(1.431 .464 .212,52)$ \\
\hline \multirow[t]{3}{*}{44} & & & \\
\hline & DANA CADANGAN & 0,00 & 0,00 \\
\hline & Dana Cadangan & 0,00 & 0,00 \\
\hline 45 & ASET LAINNYA & 53.088 .000 .00 & 0.00 \\
\hline \multirow[t]{3}{*}{46} & Tagihan Jangka Panjang & 0,00 & 0,00 \\
\hline & Kemitraan dengan Pihak Ketiga & 0,00 & 0,00 \\
\hline & Aset Tak Berwujud & 0,00 & 0,00 \\
\hline 48 & Aset Lain-lain & $53.088 .000,00$ & \\
\hline 49 & TOTAL ASET & 1.331.159.769,97 & $1.408 .487 .797,98$ \\
\hline \multirow[t]{2}{*}{50} & & & \\
\hline & KEWAJIBAN DAN EKUITAS & & \\
\hline 52 & KEWAJIBAN & $8.927 .461,00$ & $6.237 .487,00$ \\
\hline 53 & KEWAJIBAN JANGKA PENDEK & $8.927 .461,00$ & $6.237 .487,00$ \\
\hline \multirow[t]{6}{*}{54} & $\begin{array}{l}\text { Utang Perhitungan Pihak Ketiga } \\
\text { (PFK) }\end{array}$ & 0,00 & 0,00 \\
\hline & Utang Bunga & 0,00 & 0,00 \\
\hline & $\begin{array}{l}\text { Bagian Lancar Utang Jangka } \\
\text { Panjang }\end{array}$ & 0,00 & 0,00 \\
\hline & Pendapatan Diterima Dimuka & 0,00 & 0,00 \\
\hline & $\begin{array}{l}\text { Utang Perhitungan Pihak ke Tiga } \\
\text { (PPK) }\end{array}$ & 0,00 & 0,00 \\
\hline & Utang Jangka Pendek Lainnya & $8.927 .461,00$ & $6.237 .487,00$ \\
\hline 55 & KEWAJIBAN JANGKA PANJANG & 0,00 & 0,00 \\
\hline 56 & Utang Dalam Negeri & 0,00 & 0,00 \\
\hline 57 & Utang Jangka Panjang Lainnya & 0,00 & 0,00 \\
\hline
\end{tabular}




\begin{tabular}{|c|l|c|c|}
58 & & & \\
\hline 59 & EKUITAS & $\mathbf{1 . 3 2 2 . 2 3 2 . 3 0 8 , 9 7}$ & $\mathbf{1 . 4 0 2 . 2 5 0 . 3 1 0 , 9 8}$ \\
\hline 60 & Ekuitas & $(15.545 .098 .460,03)$ & $(7.112 .056 .731,02)$ \\
\hline 61 & RK PPKD & $16.867 .330 .769,00$ & $8.514 .307 .042,00$ \\
\hline & $\begin{array}{l}\text { JUMLAH KEWAJIBAN DAN } \\
\text { EKUITAS DANA }\end{array}$ & $\mathbf{1 . 3 3 1 . 1 5 9 . 7 6 9 , 9 7}$ & $\mathbf{1 . 4 0 8 . 4 8 7 . 7 9 7 , 9 8}$ \\
\hline
\end{tabular}

Hasil penelitian ini juga menemukan bahwa Inspektorat Kabupaten Enrekang menyajikan laporan neraca telah sesuai dengan penerapan PP No. 71 Tahun 2010 tentang Standar Akuntansi Pemerintahan berbasis akrual dan mengacu pada PSAP 01. Hasil penelitian ini mendukung hasil penelitian Mantiri, Saerang dan Elim (2016) yang menyatakan bahwa neraca dalam PP No.71 tahun 2010, penyajian aset disajikan menurut klasifikasi aset lancar dan aset non lancar, Penyajian kewajiban disajikan menurut klasifikasi kewajiban jangka pendek dan kewajiban jangka panjang dan penyajian ekuitas merupakan kekayaan bersih pemerintah yang merupakan selisih antara aset dan kewaiban pemerintah.

\subsection{Catatan atas Laporan Keuangan}

Catatan atas Laporan Keuangan Inspektorat Kab. Enrekang disusun sebanyak 7 bab yang terdiri dari Bab I Pendahuluan, Bab II Ekonomi Makro, Kebijakan Keuangan dan Pencapaian Target Kinera APBD Pada OPD, Bab III Ikhtisar Pencapaian Kinerja Keuangan, Bab IV Kebijakan Akuntansi, Bab V Penjelasan Pos-Pos Laporan Keuangan, Bab VI Penjelasan atas Informasi-Informasi Non Keuangan OPD dan Bab VII Penutup. Dari hasil penelitian ini diketahui bahwa Inspektorat Kabupaten Enrekang dalam menyajikan catatan atas Laporan Keuangan telah menerapkan PP Nomor 71 tahun 2010. Catatan atas Laporan Keuangan Inspektorat Kabupaten Enrekang telah sesuai dengan penerapan PP No. 71 Tahun 2010 tentang Standar Akuntansi Pemerintahan berbasis akrual, dimana CALK Inspektorat Kabupaten Enrekang telah menyajikan susunan sesuai dengan PP No. 71 Tahun 2010 tentang Standar Akuntansi Pemerintahan. Dalam penyajian Catatan atas Laporan Keuangan Inspektorat Kabupaten Enrekang menjelaskan pos-pos Laporan Keuangan berupa rincian dan penjelasan masing-masing pos Laporan Keuangan serta pengungkapan informasi yang diharuskan oleh Kebijakan Akuntansi Pemerintahan yang belum disajikan dalam lembar muka Laporan Keuangan.

Hasil penelitian ini juga menemukan bahwa Inspektorat Kabupaten Enrekang menyajikan catatan atas laporan keuangan telah sesuai dengan penerapan PP No. 71 Tahun 2010 tentang Standar Akuntansi Pemerintahan berbasis akrual dan mengacu pada PSAP 04. Hasil penelitian ini mendukung hasil penelitian Kema (2013) yang menyatakan bahwa Catatan atas Laporan Keuangan meliputi penjelasan atau daftar terinci atau analisis atas nilai suatu pos yang disajikan dalam Laporan Realisasi Anggaran, Neraca dan Laporan Arus Kas. Termasuk pula dalam Catatan atas Laporan Keuangan adalah penyajian informasi yang diharuskan dan dianjurkan oleh Pernyataan Standar Akuntansi Pemerintahan serta pengungkapan-pengungkapan lainnya yang diperlukan untuk penyajian yang wajar atas laporan keuangan, seperti kewajiban kontinjensi dan komitmen-komitmen lainnya. Hasil ini juga mendukung hasil penelitian Mentu dan Sondakh (2016) yang menyatakan bahwa Dalam Catatan atas Laporan Keuangan setiap entitas wajib menyajikan CaLK sebagai bagian yang tak terpisahkan dari laporan keuangan untuk tujuan umum. Catatan atas Laporan Keuangan dimaksudkan agar laporan keuangan dapat dipahami oleh pembaca secara luas, tidak terbatas hanya untuk pembaca tertentu. Catatan atas Laporan Keuangan Dinas Pendapatan Daerah dan Dinas Sosial Provinsi Sulawesi Utara yang menjelaskan mengenai pendahuluan, ekonomi makro, kebijakan akuntansi yang penting dan penjelasan pos-pos laporan keuangan telah mengacu pada Pernyataan Standar Akuntansi Pemerintah Nomor 4.

\subsection{Analisa Faktor Pendukung dalam Penyajian Laporan Keuangan}

Salah satu faktor pendukung dalam penyajian laporan keuangan Inspektorat Kab. Enrekang sesuai dengan PP 71 Tahun 2010 adalah sumber daya manusia. Namun terdapat kendala-kendala yang seiring dengan penerapannya. Kendala utama yang dihadapi oleh Inspektorat Kab. Enrekang dalam penerapannya adalah pegawai pengelola keuangan belum ada yang berlatar belakang pendidikan akuntansi. Mengingat perkembangan akuntansi pemerintahan di Indonesia tidak secepat perkembangan akuntansi komersial, sampai saat ini masih sedikit sumber daya manusia yang menguasai akuntansi pemerintahan. Hal ini didorong oleh masih kurangnya kepedulian pimpinan 
untuk mendasari keputusannya pada informasi keuangan. Penempatan pegawai sumber daya manusia di dalam menyajikan laporan keuangan masih jarang sekali dilandasi oleh dasar pendidikan dan kemampuan pegawai tersebut. Hal ini tercermin dari hasil penelitian bahwa Inspektorat Kab. Enrekang masih sering terlambat dalam menyajikan laporan keuangannya. Salah satu penyebabnya adalah sering terjadinya perubahan peraturan-peraturan pemerintah membutuhkan waktu yang lama dalam mensosialisasikannya secara maksimal pada pegawai atau sumber daya manusia yang terlibat dalam penyusunan dan penyajian laporan keuangan. Di samping itu setiap pegawai yang telah mengikuti pelatihan tidak menjamin bahwa mereka telah paham dalam mengoperasikan Sistem Informasi Akuntansi Pemerintah Daerah dan mampu membaca laporan keuangan serta kendala lain yaitu faktor individu atau keinginan untuk menguasai aplikasi masih kurang.

Faktor pendukung kedua adalah perangkat pendukung teknis berupa laptop dan aplikasi (software). Inspektorat Kab. Enrekang telah menggunakan Aplikasi yang diberi nama Sistem Informasi Keuangan Daerah (SIKD). Aplikasi ini merupakan aplikasi yang sediakan oleh Badan Pengelola Keuangan Daerah (BPKD) yang bekerjasama dengan pihak swasta. Penggunaan aplikasi ini diawali dengan penginputan data-data transaksi keuangan pada Buku Kas Umum dan secara otomatis melakukan penjurnalan sampai tersedianya laporan keuangan yang dibutuhkan. Namun dalam penggunaan aplikasi SIKD ini, masih terdapat kekurangan yaitu aplikasi ini belum berbasis online sehingga proses pengiriman data dan rekonsiliasi data dengan Badan Pengelola Keuangan Daerah (BPKD) masih dilakukan secara manual yang membutuhkan waktu dan biaya. Selain itu, jika terdapat permasalahan error pada aplikasi SIKD ini, perbaikan tidak dapat langsung dilakukan karena pihak swasta selaku pemilik aplikasi ini tidak selalu berada pada kantor BPKD Kab. Enrekang.

Berdasarkan hasil analisis penelitian yang telah dilakukan, maka dapat ditarik simpulan sebagai berikut: Laporan keuangan Inspektorat Kab. Enrekang telah menerapkan Peraturan Pemerintah No. 71 tahun 2010 tentang Standar Akuntansi Pemerintahan Berbasis Akrual dan telah menyajikan komponen laporan keuangan yaitu Laporan Realisasi Anggaran (LRA), Laporan Operasional (LO), Neraca, Laporan Perubahan Ekuitas (LPE) dan Catatan atas Laporan Keuangan (CaLK). Namun dalam penerapannya, terdapat kendala seperti penempatan pegawai pengelola keuangan belum ada yang berlatar belakang pendidikan akuntansi dan aplikasi keuangan yang digunakan belum berbasis online sehingga proses pengiriman data dan rekonsiliasi data hanya bisa dilakukan secara manual.

\section{Simpulan dan Saran}

Berdasarkan kesimpulan di atas, maka saran yang dapat diberikan melalui hasil penelitian ini yaitu dalam pelaksanaan penyusunan laporan keungan pada Inspektorat Kab. Enrekang, masih diperlukan sumber daya manusia yang memilliki kompetensi yang memadai seperti pegawai yang berlatar belakang pendidikan akuntansi. Disamping itu, pegawai yang bekerja pada pengelolaan keuangan Inspektorat Kab. Enrekang perlu diberikan pendidikan dan pelatihan yang memadai. Penggunaan Aplikasi pengelolaan keuangan yang digunakan pada Inspektorat Kab. Enrekang juga masih perlu dilakukan peningkatan kemampuan yang selama ini masih menggunakan aplikasi berbasis desktop menjadi aplikasi berbasis online sehingga proses pengelolaan keuangan yang dimulai dari penginputan data sampai pada penyajian laporan keuangan bisa dilakukan secara efektif dan efisien.

\section{DAFTAR PUSTAKA}

Alimbudiono, R. S., \& Andono, F. A. (2004). Kesiapan Sumber Daya Manusia Sub Bagian Akuntansi Pemerintah Daerah "XYZ" dan Kaitannya Dengan Pertanggungjawaban Keuangan Daerah Kepada Masyarakat: Renungan Bagi Akuntan Pendidik. Jurnal Akuntansi Dan Keuangan Sektor Publik, 5(02), 18-30.

Aliyah, S. (2012). Pengaruh penyajian laporan keuangan daerah dan aksesibilitas laporan keuangan daerah terhadap transparansi dan akuntabilitas pengelolaan keuangan daerah Kabupaten Jepara. Unisnu.

Bodnar, G. H., \& Hopwood, W. S. (2006). Sistem informasi akuntansi. Jakarta: Salemba Empat.

Bustamam, B., Ibrahim, R., \& Saputra, D. (2015). Analisis Penyajian Laporan Keuangan Syariah Pada Baitul Mal Provinsi Aceh. Jurnal Dinamika Akuntansi Dan Bisnis, 2(1), 82-91.

Chamidah, N., Putra, A. H. P. K., Mansur, D. M., \& Guntoro, B. (2020). Penta helix Element Synergy as an Effort to Develop Tourism Villages in Indonesia. JURNAL MANAJEMEN BISNIS, 8(1), 1-22.

Duwi, S. (2016). Analisis Kesiapan Pemerintah Daerah dalam Menerapkan Standar Akuntansi Pemerintahan (Peraturan Pemerintah Nomor 71 Tahun 2010) Studi pada Kabupaten Sarolangun. Universitas Andalas.

Eisenhardt, K. M. (1989). Agency theory: An assessment and review. Academy of Management Review, 14(1), 57-74. 
Indonesia, R. (2004). Undang-Undang Republik Indonesia Nomor 33 tahun 2004 tentang. Perimbangan Keuangan Antara Pemerintah Pusat Dan Pemerintah Daerah.

Indonesia, R. (2010). Standar Akuntansi Pemerintahan. Peraturan Pemerintah, 71.

Jensen, M. C., \& Meckling, W. H. (1976). Theory of the firm: Managerial behavior, agency costs and ownership structure. Journal of Financial Economics, 3(4), 305-360.

Kema, I. (2013). Penyajian Laporan Keuangan Daerah Berdasarkan Standar Akuntansi Pemerintahan Pada Pemerintah Kota Manado. Jurnal EMBA: Jurnal Riset Ekonomi, Manajemen, Bisnis Dan Akuntansi, 1(3).

Kiranayanti, I. A. E., \& Erawati, N. M. A. (2016). Pengaruh Sumber Daya Manusia, Sistem Pengendalian Intern, Pemahaman Basis Akrual Terhadap Kualitas Laporan Keuangan Daerah. E-Jurnal Akuntansi Universitas Udayana, 16(2), 1290-1318.

Laudon, K. C. (2007). Management information systems: Managing the digital firm. Pearson Education India.

Mentu, E. P., \& Sondakh, J. J. (2016). Penyajian Laporan Keuangan Daerah Sesuai Peraturan Pemerintah No. 71 Tahun 2010 Tentang Standar Akuntansi Pemerintahan pada Dinas Pendapatan Daerah dan Dinas Sosial Prov. Sulut. Jurnal EMBA: Jurnal Riset Ekonomi, Manajemen, Bisnis Dan Akuntansi, 4(1).

Miles, M. B., \& Huberman, A. M. (1984). Drawing valid meaning from qualitative data: Toward a shared craft. Educational Researcher, 13(5), 20-30.

Mitnick, B. M. (2015). Agency theory. Wiley Encyclopedia of Management, 1-6.

Mizruchi, M. S. (2004). Berle and Means revisited: The governance and power of large US corporations. Theory and Society, 33(5), 579-617.

Ningtyas, F. N., Poputra, A. T., \& Lambey, R. (2015). Evaluasi Penerapan Peraturan Pemerintah Nomor 71 Tahun 2010 Pada Dinas Energi dan Sumber Daya Mineral Provinsi Sulawesi Utara. Jurnal EMBA: Jurnal Riset Ekonomi, Manajemen, Bisnis Dan Akuntansi, 3(1).

Noreen, E. (1988). The economics of ethics: A new perspective on agency theory. Accounting, Organizations and Society, 13(4), 359-369.

Purba, A. R. H. K. (2017). PENERAPAN GOOD CORPORATE GOVERNANCE TERHADAP KUALITAS LAPORAN KEUANGAN PADA PEMERINTAH KABUPATEN DELI SERDANG.

Rina, A. H. P. K., Kusuma, A. H. P., Perdana, A. H., \& Rina, A. H. P. K. (2017). Pengaruh kompetensi, budaya organisasi dan motivasi terhadap kinerja dosen perguruan tinggi swasta di kota makassar. Economics Bosowa, 3(008), 88-100. https:// doi.org/10.31219/osf.io/67n8g

Sampel, I. F., Kalangi, L., \& Runtu, T. (2015). Analisis Kesiapan Pemerintah Kota Manado dalam Penerapan Peraturan Pemerintah Nomor 71 Tahun 2010 Mengenai Standar Akuntansi Basis Akrual. Jurnal EMBA: Jurnal Riset Ekonomi, Manajemen, Bisnis Dan Akuntansi, 3(1).

Satrio, M. D., Yuhertiana, I., \& Hamzah, A. (2016). Implementasi Standar Akuntansi Pemerintah Berbasis Akrual di Kabupaten Jombang. Jurnal Akuntansi Dan Keuangan, 18(1), 59-70.

Sipahutar, A. F. (2018). Implementasi Peraturan Pemerintah Nomor 58 Tahun 2005 Tentang Pengelolaan Keuangan Daerah Dalam Rangka Peningkatan Kinerja Badan Pengelolaan Keuangan Dan Aset Daerah Di Kabupaten Labuhan Batu.

Sugiyono, P. (2011). Metodologi penelitian kuantitatif kualitatif dan R\&D. Alpabeta, Bandung. 